This is the final peer-reviewed accepted manuscript of

Bell, Phil R.; Fanti, Federico; Hart, Lachlan J.; Milan, Luke A.; Craven, Stephen J.; Brougham, Thomas; Smith, Elizabeth: Revised geology, age, and vertebrate diversity of the dinosaur-bearing Griman Creek Formation (Cenomanian), Lightning Ridge, New South Wales, Australia. PALAEOGEOGRAPHY PALAEOCLIMATOLOGY PALAEOECOLOGY, 514. 0031-0182

DOI: 10.1016/j.palaeo.2018.11.020

The final published version is available online at:

http://dx.doi.org/10.1016/j.palaeo.2018.11.020

Rights / License:

The terms and conditions for the reuse of this version of the manuscript are specified in the publishing policy. For all terms of use and more information see the publisher's website.

This item was downloaded from IRIS Università di Bologna (https://cris.unibo.it/)

When citing, please refer to the published version. 


\title{
Revised geology, age, and vertebrate diversity of the dinosaur-bearing Griman Creek Formation (Cenomanian), Lightning Ridge, New South Wales,
} Australia

\author{
Phil R. Bell ${ }^{\mathrm{a}, *}$, Federico Fanti ${ }^{\mathrm{b}, \mathrm{c}}$, Lachlan J. Hart ${ }^{\mathrm{a}}$, Luke A. Milan ${ }^{\mathrm{a}}$, Stephen J. Craven ${ }^{\mathrm{d}}$, \\ Thomas Brougham ${ }^{\mathrm{a}}$, Elizabeth Smith ${ }^{\mathrm{e}}$ \\ ${ }^{a}$ School of Environmental and Rural Science, University of New England, Armidale, New South Wales 2351, Australia \\ ${ }^{\mathrm{b}}$ Dipartimento di Scienze Biologiche, Geologiche e Ambientali, Alma Mater Studiorum, Università di Bologna, Via Zamboni 67, 40126 Bologna, Italy \\ ${ }^{\mathrm{c}}$ Museo Geologico Giovanni Capellini, Università di Bologna, via Zamboni 63, 40126 Bologna, Italy \\ ${ }^{\mathrm{d}}$ ARC Centre of Excellence for Core to Crust Fluid Systems (CCFS) and GEMOC, Macquarie University, Sydney, NSW 2109, Australia \\ ${ }^{\mathrm{e}}$ Australian Opal Centre, Lightning Ridge, NSW, Australia
}

A R T I C L E I N F O

Keywords:

Dinosauria

Cretaceous

Eromanga Sea

Gondwana

Surat Basin

Vertebrate fossils

\begin{abstract}
A B S T R A C T
The mid-Cretaceous Griman Creek Formation (GCF), which crops out near the town of Lightning Ridge in the Surat Basin of north-central New South Wales, Australia, is noteworthy for its opalised vertebrate fauna. The fossil assemblage comprises remains of aspidorhynchid teleosts, lamniform chondrichthyans, dipnoans, chelid and possible meiolaniform turtles, leptocleidid-like and possible elasmosaurid plesiosaurians, anhanguerian pterosaurs, titanosauriform sauropods, megaraptoran theropods, ankylosaurians, several forms of non-iguanodontian and iguanodontian ornithopods, crocodylomorphs, enantiornithine birds, and stem and true monotremes, making it one of the most diverse mid-Cretaceous terrestrial vertebrate faunas in Australia. A detailed stratigraphic survey of twenty subterranean opal mines provides new information on the geology, age and palaeoenvironment of the main fossil-bearing beds. Vertebrate remains derive from the 'Finch Clay facies', laterally-extensive but discontinuous lenses of claystone that likely accumulated relatively rapidly in near-coastal but freshwater embayments (i.e. lagoonal conditions), and probably represent a single, roughly contemporaneous fauna. U-Pb age dating of detrital zircons extracted from a distinct layer of volcanogenic claystone immediately overlying one of the opalised fossil-bearing layers yields a maximum depositional age of 100.2-96.6 Ma. These new dates confirm an early to mid-Cenomanian age for the fauna, rather than Albian, as has been reported previously. The GCF at Lightning Ridge is therefore equivalent to the middle part of the Winton Formation (Queensland) and several million years older than the sauropod-dominated fauna at Winton.
\end{abstract}

\section{Introduction}

Australia's Cretaceous fossil record of terrestrial vertebrates remains one of the most poorly sampled in the world. Broadly speaking, this record is limited to the 'mid'-Cretaceous deposits of eastern Australia, including the Eromanga Basin in central Queensland (Albian-Turonian; including the fossiliferous Allaru Mudstone and Mackunda, Winton and Toolebuc formations), the Gippsland and Otway basins (Barremian-Albian; including the Strzelecki and Otway groups, respectively) in coastal Victoria, and the Surat Basin (Albian-Cenomanian [this study]; including the Griman Creek Formation) in north-central New South Wales and south-east Queensland (e.g., Rich and Rich, 1989; Dettman et al., 1992; Rich and Vickers-Rich, 1999; Molnar, 1996, 1999,
2011; Molnar and Willis, 2001; Hocknull et al., 2009; Poropat et al., 2016, 2018). Additionally, the importance of dinosaur tracksites in the older Broome Sandstone (Valanginian-Barremian) exposed near Broome in Western Australia has now been firmly established (Thulborn, 2012; Salisbury et al., 2016).

Despite earlier work on palynology (e.g., Burger, 1980, 1990; Dettmann, 1963; Helby et al., 1987; Partridge, 2006; Wagstaff et al., 2012), absolute dates and tightly-constrained geological frameworks have been lacking for key units in each of the Eromanga, Surat, Otway, and Gippsland basins, thus limiting the scope of meaningful comparisons between each of these areas (Fig. 1). Major advances in our understanding of the chronostratigraphy and palaeoenvironment of parts of the Eromanga Basin—specifically, the Winton Formation-have been

\footnotetext{
* Corresponding author.

E-mail address: pbell23@une.edu.au (P.R.

Bell).
} 


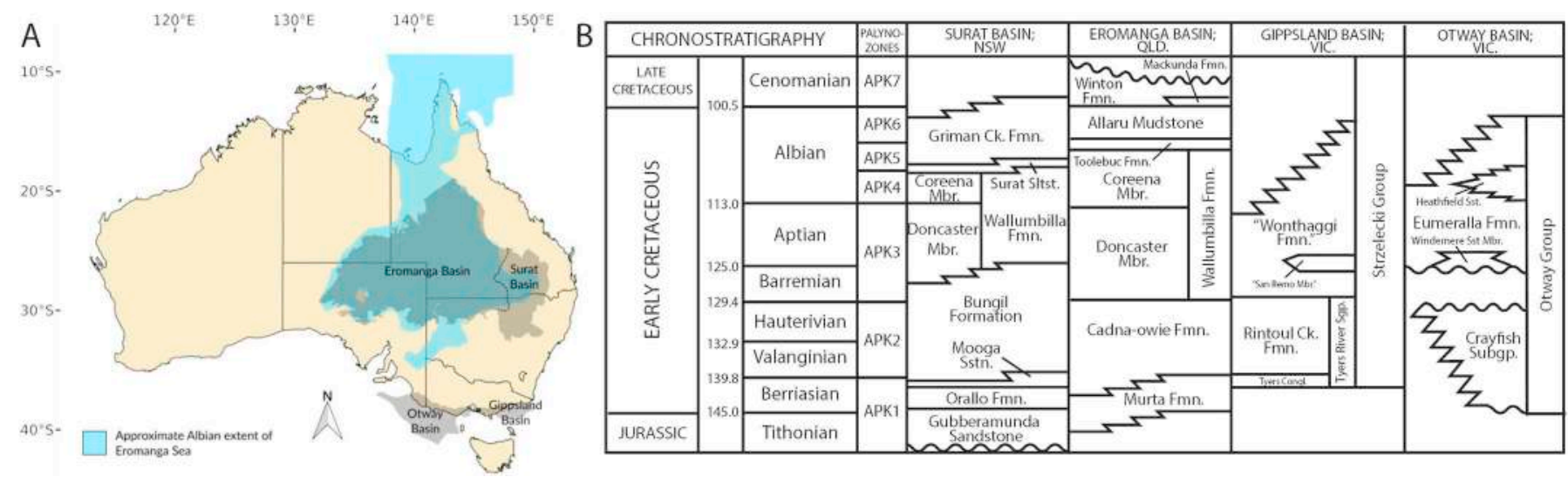

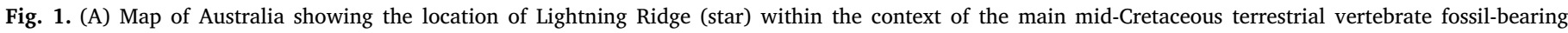

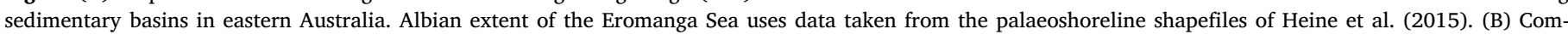

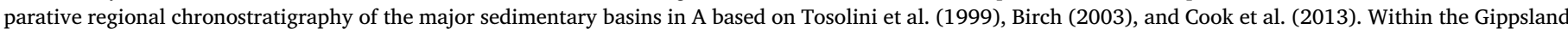
Basin, the Eumeralla Formation-equivalent beds have been referred to as the 'Wonthaggi Formation' (e.g., Rich and Rich, 1989; Rich and Vickers-Rich, 1999).

achieved by the work of Tucker et al. (2013, 2017). These papers identified the time inclusivity ( $\sim 103.0-93.9 \mathrm{Ma})$ as well as the mosaic palaeoenvironments represented at the various central Queensland localities where the Winton Formation is exposed. Thus, their work was the first to demonstrate that the rich sauropod-dominated fauna preserved near the town of Winton is neither temporally or palaeoenvironmentally equivalent to the crocodyliform and teleost-dominated fauna at Isisford (Tucker et al., 2013, 2017).

Within New South Wales, the Griman Creek Formation (GCF), which is part of the Surat Basin, is the only Cretaceous-aged terrestrial deposit that reliably yields terrestrial vertebrate material. The only other similarly-aged vertebrate-bearing unit in New South Wales, the poorly sampled Aptian Wallumbilla Formation at White Cliffs, is strictly marine and includes marine invertebrates, vertebrates and extremely rare evidence of terrestrial forms (e.g., AM F57843, a possible theropod phalanx; Molnar, 1980a). The GCF has also been considered to occupy an important 'intermediate' position-both geographically and potentially chronologically-between the better-known penecontemporaneous deposits of the Eromanga Basin in central Queensland and the Otway and Gippsland basins in Victoria (Fig. 1; Bell et al., 2016). Therefore, an improved understanding of its fauna as well as its stratigraphic and environmental setting has the potential to inform questions related to latitudinal/climatic gradients and evolutionary and biogeographic pathways in eastern Australia during the mid-Cretaceous. The first vertebrate remains from the GCF were described in the early part of the 20th Century (Smith Woodward, 1910; Chapman, 1914; Etheridge, 1917; von Huene, 1932). Despite a period of renewed interest in the 1980s and 1990s and the rich fauna that was subsequently revealed, aside from a number of popular books (Smith, 1999; Kear and Hamilton-Bruce, 2011), there have been few attempts to synthesise what is known of this fauna (e.g. Dettman et al., 1992; Smith, 2009; Meakin, 2011). The aims of this study are to provide: (1) new sedimentological and palaeoenvironmental interpretations of the GCF at Lightning Ridge; (2) the first depositional age for this formation at Lightning Ridge based on U-Pb age dating of detrital zircons, and; (3) a brief review of the vertebrate fauna from the GCF, based primarily on the literature.

\section{Geological setting}

The Griman Creek Formation (GCF) is a sedimentary unit measuring up to $400 \mathrm{~m}$ in thickness confined to the Surat Basin between the towns of Lightning Ridge (New South Wales) and Surat (Queensland) further to the north (Reiser, 1970; Exon, 1976; Green et al., 1997; Price, 1997; Bell et al., 2016). Overall, the GCF comprises thinly-bedded and interlaminated fine- to medium-grained sandstone, siltstone, mudstone and minor coal. Thick sandstone beds and intraformational conglomerates are common in the Lightning Ridge area. Although a complete, formal subdivision of this unit has not been proposed, Green et al. (1997) indicate a conformable contact with the underlying Surat Siltstone and an increase in conglomerates and coal seams up-section, a trend coupled with an increase of fresh-water invertebrates (bivalves). Based on sedimentological, palynological, and palaeontological data, Exon (1976) and Green et al. (1997) also interpreted the GCF as a relatively complex succession of initially regressive beach or nearshore marine deposits, followed by paralic to deltaic conditions with the upper sequence accumulating on a fluvial floodplain. The change from a littoral to freshwater environment in the GCF marks the retreat of the Eromanga Sea, which was initiated in the Albian. Numerous geological investigations including seismic and biostratigraphic data are available (e.g. Senior and Chadderton, 2007; Rey, 2013) that are relevant to this study; however, it is important to remark that previous detailed contributions to our comprehension of the GCF depositional environment are based primarily on subsurface data collected in the northern part of the Surat Basin between Goondiwindi, Wandoan and Morven in Queensland, between 150 and $350 \mathrm{~km}$ from Lightning Ridge where the majority of palaeontological evidence derives. Fission-track analyses on core samples from the GCF in Queensland indicate an age of $\sim 107 \mathrm{Ma}$, with sedimentation ceasing at $\sim 99 \mathrm{Ma}$ (Raza et al., 2009). Similarly, palynological evidence (reference unit APK5; Coptospora paradoxa spore-pollen zone) support a middle Albian age (Burger, 1980; Dettman et al., 1992; Price, 1997 and references therein). Basin-scale correlations indicate the Queensland exposures of the GCF are coeval to the Toolebuc and Allaru formations within the Eromanga Basin to the northwest (Haig and Lynch, 1993; Gray et al., 2002; Cook, 2012). The GCF was deposited at a palaeolatitude of $\sim 60^{\circ} \mathrm{S}$ (Hay et al., 1999; Matthews et al., 2016) and therefore its associated fauna in the Lightning Ridge area is here considered as representative of a high-latitude ecosystem.

Despite these data, there is a notable deficiency of precise geological information from the key fossil-bearing region around Lightning Ridge. In the Lightning Ridge area, sedimentary sequences of the GCF have been divided into two informal members, the Wallangulla Sandstone member and the overlying Coocoran Claystone member (Moore, 2002). Subterranean exposures of the Wallangulla Sandstone exceed $25 \mathrm{~m}$ (thickness) of predominantly fine-grained, clayey sandstone and include the 'Finch Clay facies' (Scheibner and Basden, 1998), a series of discontinuous opal and fossil-bearing claystone lenses distributed throughout the Wallangulla Sandstone and composed primarily of kaolinite, smectite and illite clay minerals. The overlying Coocoran 
Claystone member generally occurs as a $\leq 10 \mathrm{~m}$ thick, $\mathrm{f}$ ine-grained claystone unit. The entire sedimentary sequence is also characterized by minor normal $f$ aults and subvertical breccia 'pipes' ( or ' blows', see Sedimentology below) that cut almost vertically i nto sedimentary layers. New data presented here are therefore i nvaluable to our knowledge of the GCF and related $\mathrm{f}$ ossil fauna, i ts time i nclusiveness, as well as providing an i mportant step towards linking previously pub-lished g eological sections i $\mathrm{n}$ the north (e.g. Exon, 1976; Green et al., 1997) to the southern part of the S urat Basin.

\section{Opal mine localities}

In the study area around Lightning Ridge $\left(29^{\circ} 25^{\prime} 40.11^{\prime \prime} \mathrm{S}\right.$, $147^{\circ} 58^{\prime} 44.14^{\prime \prime} \mathrm{E}$ ), the Griman Creek Formation (GCF) is restricted to a series of NW-SE trending ridges that rise from the surrounding black soil plains. Surface outcrop is virtually lacking; however, more than a century of extensive opal mining on these ridges provides a unique opportunity to observe geological features as fresh exposures underground. Each mine typically consists of a vertical shaft $(1 \mathrm{~m}$ in diameter and $\sim 6-20 \mathrm{~m}$ deep), which in older workings may lead to tens-tohundreds of metres of horizontal tunnels ('drives') and more spacious chambers ('ballrooms') at various depths between one to $30 \mathrm{~m}$. Geological observations for this study were made almost exclusively in private mines between August 18-28, 2015. In total, 20 underground mines were investigated across the main mining areas of the 'Three Mile', 'Ten Mile', Coocoran, and Glengarry/Sheepyard opal fields primarily to the $\mathrm{N}$ and SW of Lightning Ridge (Fig. 2A). In addition, observations were also made at the open-cut mine at Lunatic Hill on the 'Three Mile' field near the township of Lightning Ridge. Data presented in this study encompass an area $50 \times 35 \mathrm{~km}$ allowing for the construction of a composite section representative of $\sim 30 \mathrm{~m}$ of the GCF as it occurs at Lightning Ridge (Fig. 2B), although out of necessity it does not take into account the wider areal extent of the formation, which extends for several thousand square kilometres from central-western
NSW into southern Queensland.

\section{Sedimentology}

Access to multiple private mines permitted the observation of sedimentological features of both the Wallangulla Sandstone and overlying Coocoran Claystone members as well as marker beds useful for stratigraphic correlations across the area. All mines extend into the Wallangulla Sandstone member where opal and opalized fossils are collected almost exclusively from the 'Finch Clay' lenses (Bell et al., 2016). Fresh exposures allowed for detailed sedimentological observations, including the identification of major stratigraphic markers. Palaeocurrent directions were measured from various sedimentary features, predominantly trough cross-bedding structures $(n=280)$.

\subsection{Facies description}

The lower parts of the Wallangulla Sandstone deposits include fining-up sequences of reddish fine-grained sandstones, light-coloured siltstones, and light grey claystone (Fig. 3). Beds are laterally discontinuous, finely laminated with frequent alternation of silt and clay layers. Locally, sandy deposits display cross stratification $(2-5 \mathrm{~cm}$ thick) and loading/water-escape structures. Overall, in the Lightning Ridge area the Wallangulla Sandstone deposits exceed $30 \mathrm{~m}$ in thickness. Within the Wallangulla Sandstone, narrow and discontinuous lenses of the 'Finch Clay facies' represent the primary source of commercial opal and opalized fossils so far. These lenses are characterized by finelylaminated clay locally cut by fine-grained channel deposits displaying a sharp, erosive contact and wedging over a relatively short distance (1 to 5 m; Fig. 4A, B). Rooting structures, decapod gastroliths (Smith, 2009) and unionid bivalves (Newton, 1915; McMichael, 1956; Hocknull, 1997; Kear and Godthelp, 2008) are found throughout this interval.

At two localities (Molyneux and Hard Hill, both within the Coocoran opal field; Fig. 2A), the uppermost Finch Clay layer includes a

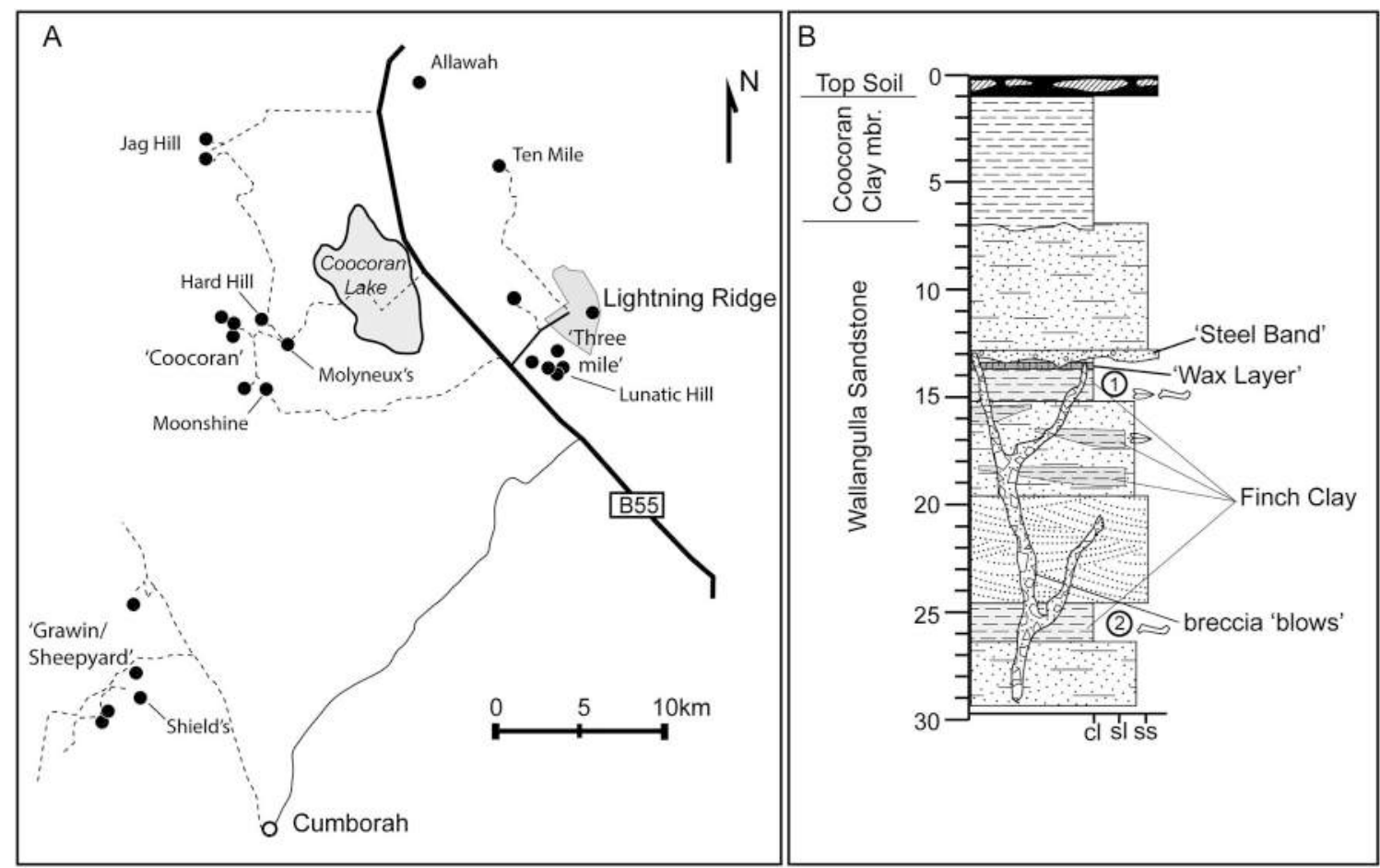

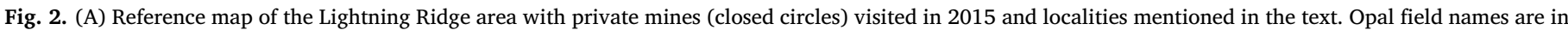

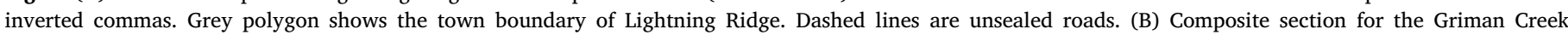

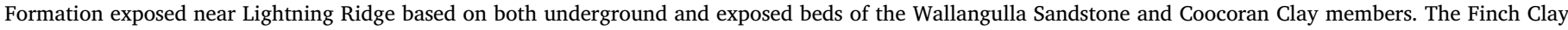
facies levels one and two are denoted by numerals. The 'waxy band' was used for radioisotopic analyses. 

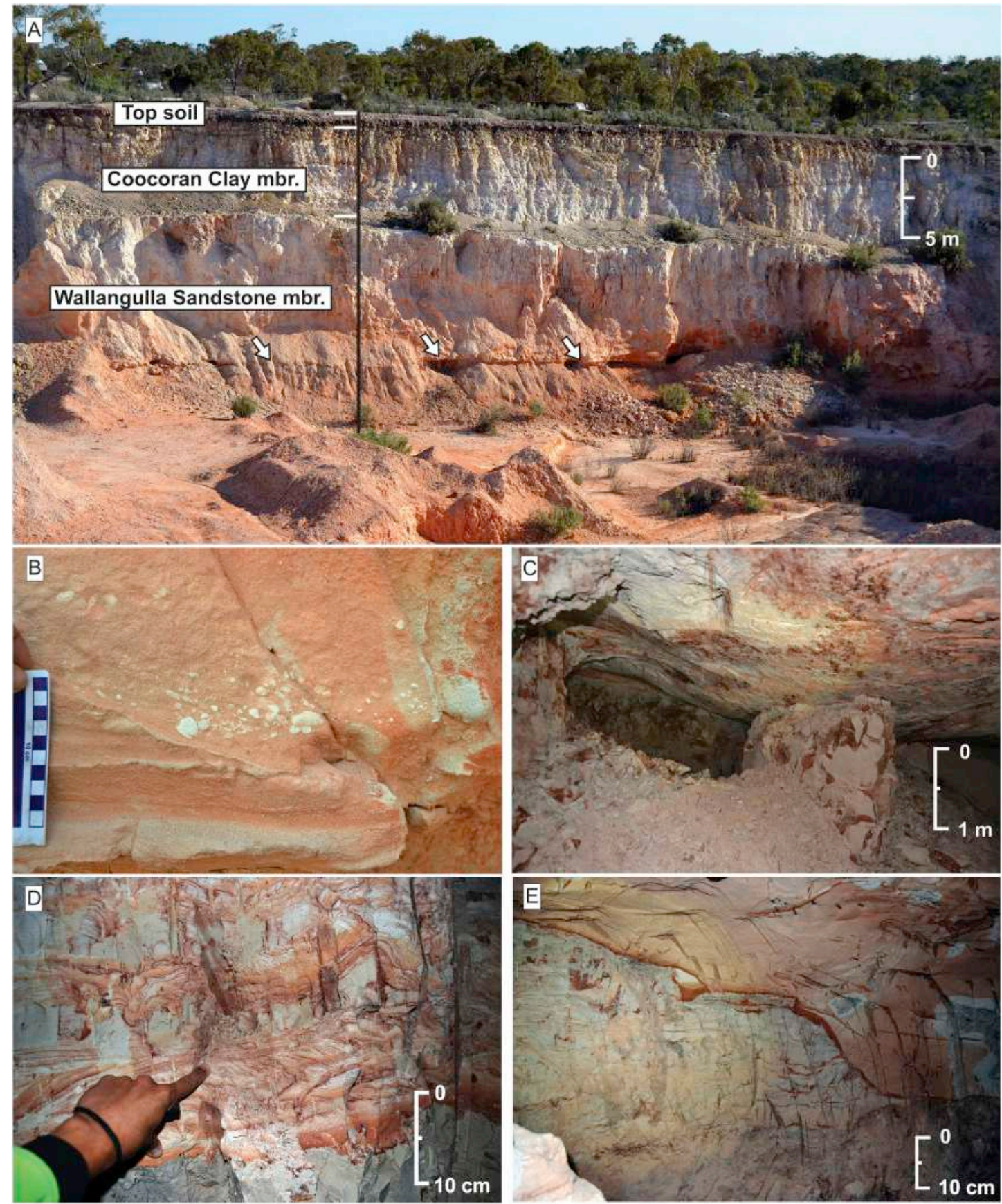

Fig. 3. (A) Exposed section of the Griman Creek Formation at the open-cut mine at Lunatic Hill near Lightning Ridge. White arrows mark the 'steel band', a marker bed in the area. The 'first' level of the Finch Clay facies, the main fossil bearing horizon, immediately underlies the 'steel band'. Height of exposure is $\sim 11 \mathrm{~m}$. (B) Coarse-grained sandstones of the Wallangulla Sandstone mbr. commonly contain extraformational and rip-up clasts; (C) The sharp, basal contact of the 'steel band' layer is used as a natural roof by miners in the area. The surface often displays flute/groove casts but also indeterminate plant remains and rare unionid bivalves. Width of view is $\sim 3 \mathrm{~m}$. (D) Example of fine-grained, cross-bedded deposits deformed by water escape in the Finch Clay interval. Scale $=10 \mathrm{~cm}$. (E) Horizontally laminated 'Finch Clay facies' are locally cut by erosive, lenticular, channel deposits consisting of reddish, fine-grained sandstone and silt. Scale $=10 \mathrm{~cm}$.

$5-25 \mathrm{~cm}$ thick layer of dark grey, bentonitic clay locally referred to as the 'waxy band' (Figs. 2B, 4C, D). This layer lies immediately below the 'steel band' marker bed (see below) and the uppermost claystone layer ('Finch Clay facies'). The 'waxy band' has sharp lower and upper contacts, and occurs within a $120 \mathrm{~cm}$ thick package of finely-laminated, bentonite-like clay. Although limited in its occurrence, the 'waxy band' represents the first chronostratigraphic tool for determining the age of the fossil beds in the area. The upper 6-8 $\mathrm{m}$ of the Wallangulla Sandstone member mark a shift to coarser lithologies. Although anecdotes from miners suggest claystone lenses are variably present in these upper parts, they were not observed during the course of this study. A thin (up to $30 \mathrm{~cm}$ ) but laterally continuous, heavily silicified layer, known locally as 'steel band', marks this transition to coarser lithologies and acts as a reliable marker bed in some areas. This resistant layer is exposed to form the roof of many mines, which offers the opportunity to document flute and groove casts as well as indeterminate plant material and freshwater unionid bivalves. Overlying deposits of the Wallangulla Sandstone include cross-bedded sandstones with common rip-up clasts that gradually become tabular and interbedded with siltstone and rare claystone. These uppermost deposits of the Wallangulla Sandstone 

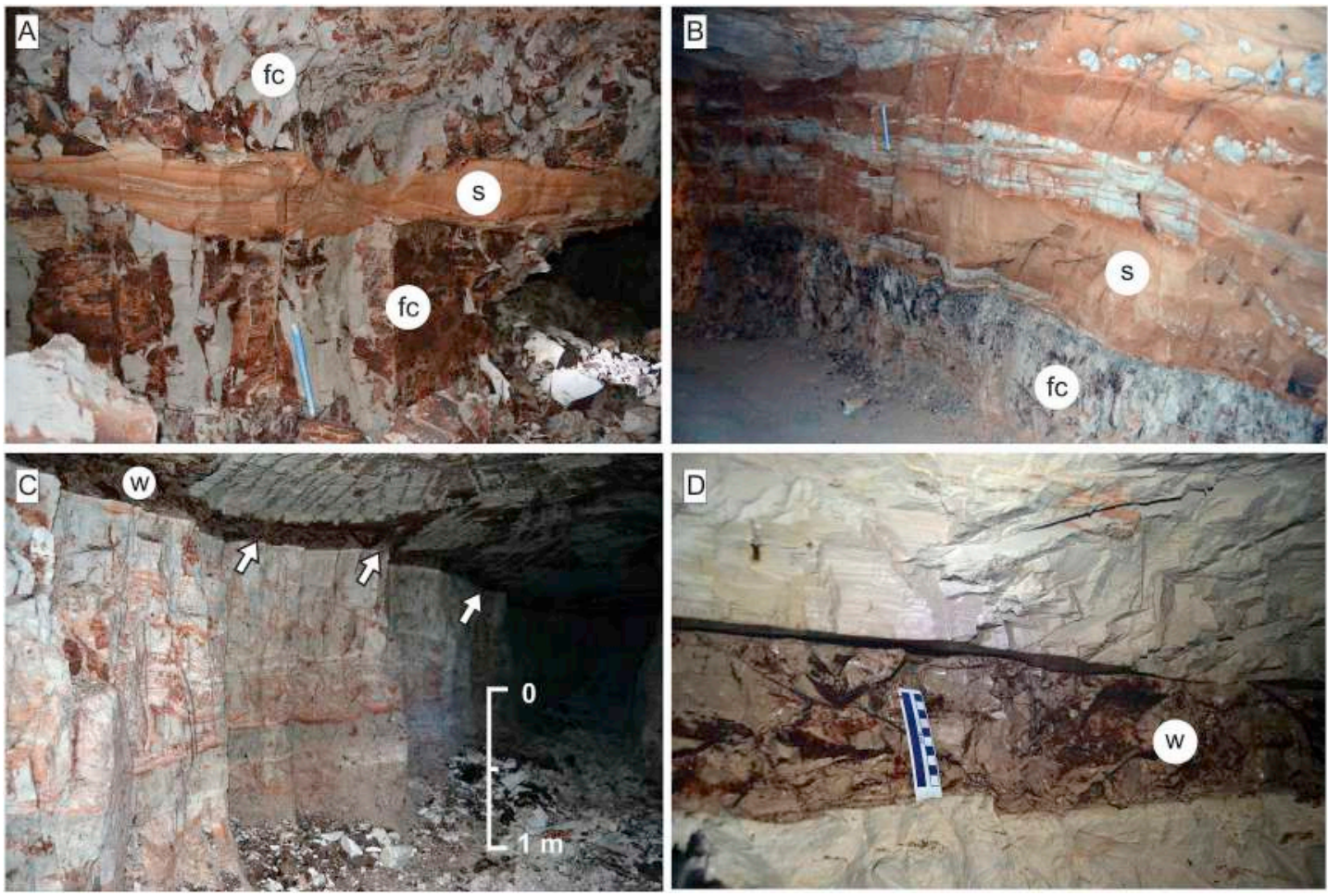

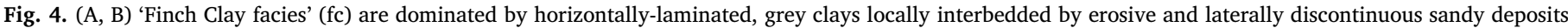

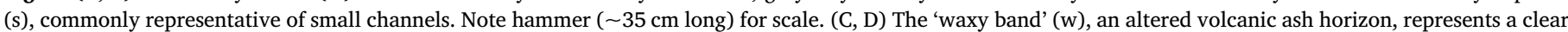

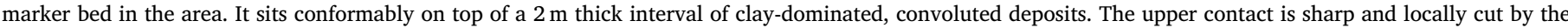
'steel band' layer. The irregular lower (arrows) and upper boundaries in C are an artefact of mining activity. Height of tunnel in C is $\sim 180 \mathrm{~cm}$.

accumulated under higher energy flows compared to the underlying observable sediments, documenting an overall trend towards more fluvially-dominated environments. Palaeoflow measurements are consistent with a predominant current direction to the N/NE. Finally, the contact with the overlying Coocoran Claystone member is sharp and unconformable. The Wallangulla Sandstone and Coocoran Claystone also display zones of angular, fractured rock (breccia pipes), which are referred to by miners as 'blows' or 'verticals'. Such structures are generically sub-vertical and range from a few centimetres to more than $2 \mathrm{~m}$ in width, and extend for tens of meters vertically.

To further support depositional interpretations, rock samples representative of the Wallangulla Sandstone beds were collected for petrographic analyses. In particular, we collected sediments representative of the 'Finch Clay facies' (both clay-dominated and channel deposit intervals) and the 'steel band' (Fig. 5). Samples representative of the 'steel band' collected at Lunatic Hill, Grawin, and Moonshine localities preserve relatively poorly sorted, medium-grained detrital clasts with common quartz and carbonatic grains. 'Finch Clay' beds from Lunatic Hill, Molyneux, Hard Hill, and Shield localities are characterized by very fine and well-sorted grains, with frequent secondary quartz/opal components. Petrographic analyses indicate relatively immature, fine-grained sandstones forming the 'steel band' marker layer. Conversely, rounded, well-sorted grain sediments in the 'Finch Clay' support a mature sediment that accumulated under stable deposition in shallow waters.

In addition to sedimentary evidence, the GCF also preserves an exceptionally diverse and abundant record of freshwater invertebrates, including decapod gastroliths (Smith, 2009), thiarid (Hamilton-Bruce et al., 2004), viviparid (Hamilton-Bruce et al., 2002; Hamilton-Bruce and Kear, 2006), and succineid gastropods (Hamilton-Bruce and Kear, 2010), as well as hyriid (Hocknull, 2000) and unionid bivalves (Newton, 1915; McMichael, 1956; Hocknull, 1997; Kear and Godthelp, 2008).

\subsection{Palaeoenvironmental interpretation of fossil beds}

Discussed exposures of the GCF support high sediment supply, minor channel/high-energy deposits, and extensive, clay-dominated, horizontally-laminated beds. Both deposits and faunal assemblages are consistent with a low-energy, coastal lowland characterized by shallow waters and significant fluvial sediment discharge. Specifically, vertebrate and invertebrate fossil remains are interpreted to have accumulated in freshwater lakes, some of which maintained distal connections (as evidenced by the overwhelmingly freshwater signal of the invertebrate fauna) to the marine Eromanga Sea to the north and northwest, that permitted intermittent access to rare marine taxa (e.g., aspidorhynchid teleosts, sharks, plesiosaurs; see Vertebrate diversity below). Central to this reasoning is the absence of marine invertebrates (e.g. ammonites, belemnites, crinoids, naticid gastropods) and certain vertebrate groups (e.g. ichthyosaurs), which are a ubiquitous component in nearby marine deposits, such as of the Aptian Wallumbilla Formation (specifically, the Doncaster Member) exposed at White Cliffs $450 \mathrm{~km}$ west of the study area (Day, 1969; Henderson et al., 2000; Kear, 2005). The mix of terrestrial (e.g., dinosaurs and undescribed plant remains) and freshwater (e.g., gastropods, bivalves) forms together with rare marine taxa (see Vertebrate diversity) suggests complex origins for the fossil assemblage, and caution is required in view of the tiny percentage of specimens representing taxa that in other fossil locations occur in marine settings, and variability of fossil assortments across the Lightning Ridge region.

\section{Zircon geochronology}

A distinct volcanogenic clay layer (locally known as 'waxy band') was sampled for detrital zircon geochronology at the Hard Hill locality at a depth of $12 \mathrm{~m}$, approximately $4 \mathrm{~km}$ to the southwest of Coocoran Lake (Fig. 2A). The 'waxy band' occurs at only two small sites at the Coocoran opal field (Molyneux and the Hard Hill localities), where it 

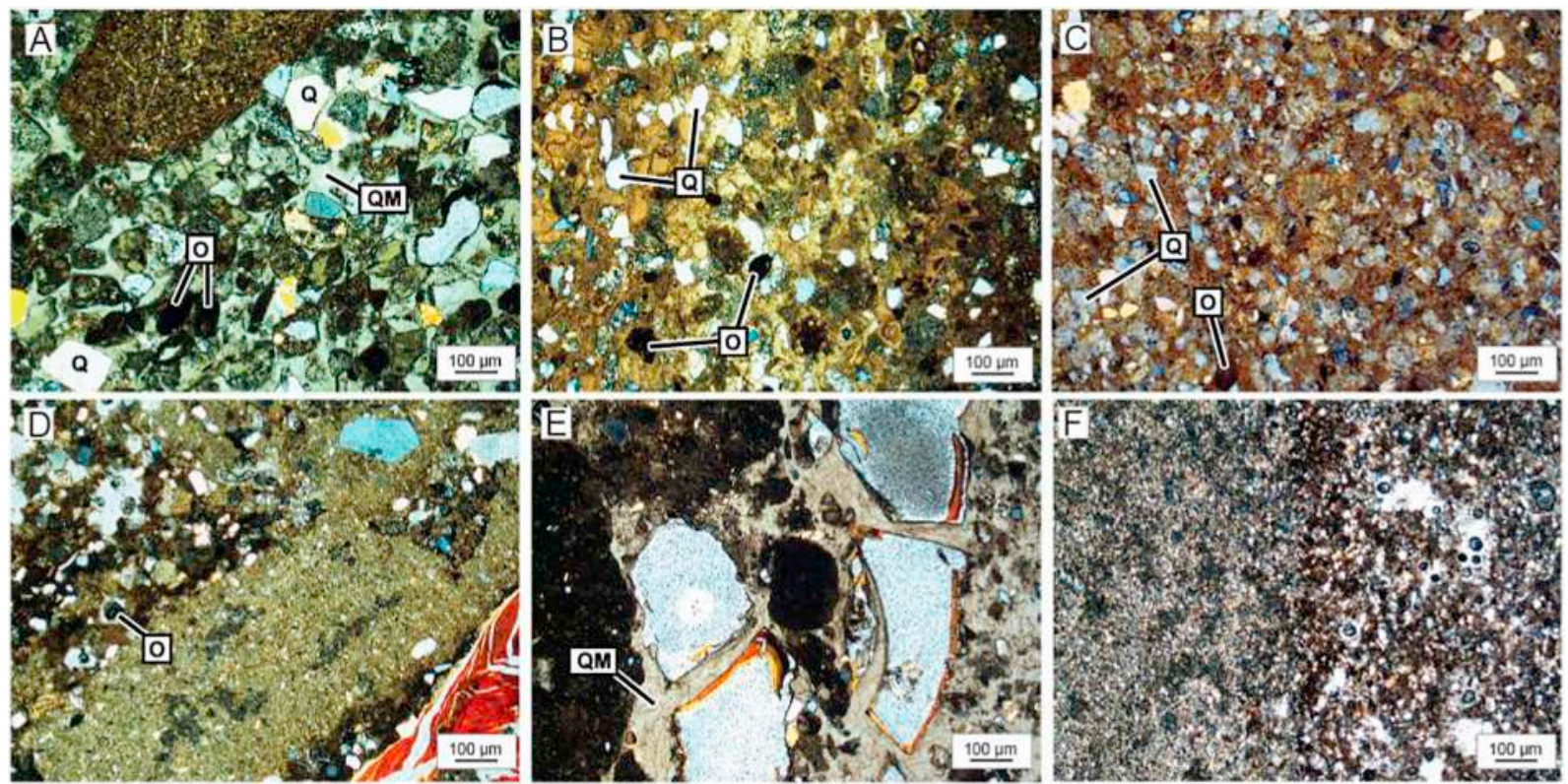

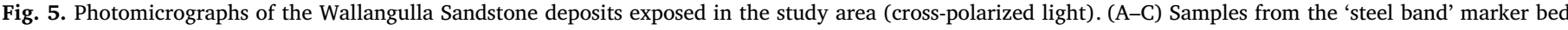

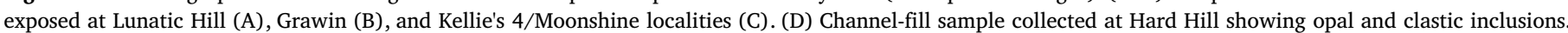

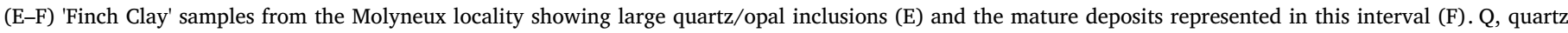
clasts, QM, quartz/opaline matrix; O, oxides.

lies between the 'steel band' marker bed (above) and the uppermost fossil- and opal-bearing claystone (below; see Geological setting; Fig. 2B). Although zircons obtained from this layer are taken to constrain the maximum age of the fossil biota in and around Lightning Ridge, they do not-and nor are they intended to-necessarily provide context for significantly deeper parts of the Griman Creek Formation (up to $200 \mathrm{~m}$ ) or to exposures of the GCF elsewhere in the Surat Basin. Identification of the 'waxy band' mineralogy was undertaken by X-Ray Diffraction (XRD). Samples were mounted into a $27 \mathrm{~mm}$ sample holder and diffractograms were collected from $5^{\circ}$ to $90^{\circ} 2 \mathrm{q}$ using a PANalytical Aeris Research edition diffractometer, with $600 \mathrm{w}$ CuKa source. Identification of the phases was completed using PANalytical HighScore+ software with PDF4+ and PAN ICSD databases.

\subsection{Zircon separation}

A two-kilogram sample of the volcanogenic claystone was extracted from a $\leq 25 \mathrm{~cm}$ thick horizon at the Hard Hill locality for zircon separation. This lithologically distinct layer of clay ('waxy band') was suspected at the time to be a reworked volcanic airfall tuff, and therefore was specifically selected to hopefully provide a stratigraphic age for the local exposures of the formation. Zircon extraction was performed by first disaggregating the rock to liberate the zircon using a SELFRAG ${ }^{\circledast}$ (a high voltage electric pulse selective fragmentation in-strument), followed by screening at size ranges suitable for subsequent traditional separation procedures. Screen sizes employed were $600 \mu \mathrm{m}$ and $300 \mu \mathrm{m}$. Zircon separation was performed on the $<300 \mu \mathrm{m}$ mate-rial. This material was first panned using a Lotok to remove the bulk of the less dense material. The heavy fraction was then separated mag-netically using a Frantz magnetic barrier separator followed by heavy liquid separation in sodium polytungstate solution. Zircon is con-centrated in this fraction because it is non-magnetic and denser than sodium polytungstate (specific gravity: 3.1 ).

\subsection{Zircon analysis}

Zircon grains were hand-picked from the concentrate onto a doublesided adhesive and mounted in epoxy resin. The resin mount was polished with $1 \mu \mathrm{m}$ diamond paste to reveal the internal structure of the grains. All grains were imaged with cathodoluminescence (CL) using a scanning electron microscope (JEOL SEM JSM-6010LV) with a Robinson CL detector at the University of New England. U-Pb age dating of the zircons was undertaken by the LAM-ICPMS technique at CCFS GAU laboratories at Macquarie University, Sydney. The isotope data were processed using the ISOPLOT program (Ludwig, 2003, 2009). LAMICPMS U-Pb-Th isotope analyses were carried out using Agilent 7700 quadrupole ICP-MS instruments, attached to a Photon Machines Excimer $193 \mathrm{~nm}$ laser system. The analyses were carried out with a beam diameter of ca $25 \mu \mathrm{m}$ with $5 \mathrm{~Hz}$ repetition rate and energy of around $0.06 \mu \mathrm{J}$ and $8 \mathrm{~J} / \mathrm{cm}^{2}$. The beam size was reduced to ca $25 \mu \mathrm{m}$ because of the abundance of very small zircons. The analytical proce-dures for the $\mathrm{U}-\mathrm{Pb}$ dating have been described in detail previously (Jackson et al., 2004). A very fast scanning data acquisition protocol was employed to minimise signal noise. Data acquisition for each analysis took 3 min (1 min on background, 2 min on signal). Ablation was carried out in He to improve sample transport efficiency, provide more stable signals and give more reproducible $\mathrm{Pb} / \mathrm{U}$ fractionation. Provided that constant ablation conditions are maintained, accurate correction for $\mathrm{U} / \mathrm{Pb}$ fractionation can then be achieved using an iso-topically homogeneous zircon standard.

Samples were bracketed at the beginning and end by pairs of analyses of the GEMOC GJ-1 zircon standard (Elhlou et al., 2006). This standard is slightly discordant and has a TIMS ${ }^{207} \mathrm{~Pb} /{ }^{206} \mathrm{~Pb}$ age of 608.5 Ma (Jackson et al., 2004). The other well-characterized zircon standard 91,500 and Mud Tank were also analysed within the run as an independent control on reproducibility and instrument stability. U-Pb ages were calculated from the raw signal data using the online software package GLITTER (www.mq.edu.au/GEMOC; Griffin et al., 2008). GLITTER calculates the relevant isotopic ratios for each mass sweep and displays them as time-resolved data. This allows isotopically homogeneous segments of the signal to be selected for integration. GLITTER then corrects the integrated ratios for ablation related fractionation and instrumental mass bias by calibration of each selected time segment against the identical time segments for the standard zircon analyses. 


\subsection{Maximum depositional age calculation method}

We utilise the same methodologies employed by Tucker et al. (2013) to calculate the maximum depositional age of the GCF in the Lightning Ridge district in order to compare our results with those reported for dinosaur faunas hosted in the Winton Formation, Queensland. To determine the maximum depositional ages of the GCF, the following methodologies were used: 1) Youngest single grain age (YSG); 2) youngest set of grains age (or youngest detrital zircon age YDZ); 3) weighted average of three youngest grains (WA +3 grains); 4) zircon age extractor known as the 'TuffZirc' calculation ( +6 grains); and 5) the youngest graphical peak (YPP) (Dickinson and Gehrels, 2009; Ludwig, 2003, 2009; Tucker et al., 2013).Zircon U$\mathrm{Pb}$ results that were $>10 \%$ discordant were not used for age calculations.

\subsection{Zircon results}

Zircons were the dominant component of the heavy mineral $\mathrm{f}$ raction, with grains ranging $\mathrm{f}$ rom $\sim 40 \mu \mathrm{m}$ to over $\sim 200 \mu \mathrm{m}$ on their long axis. Two distinct $g$ roups of zircon $g$ rains were recovered $f$ rom the sample. Group one contained a simple population of $\mathrm{clear}$ euhedral prismatic to elongate prismatic grains (Fig. 6). They all exhibit oscil-latory magmatic zoning. They range $i \mathrm{n}$ length $\mathrm{f}$ rom 40 $\mu \mathrm{m}$ to $100 \mu \mathrm{m}$, and are commonly $50-60 \mu \mathrm{m}$. Their length to width ratios are

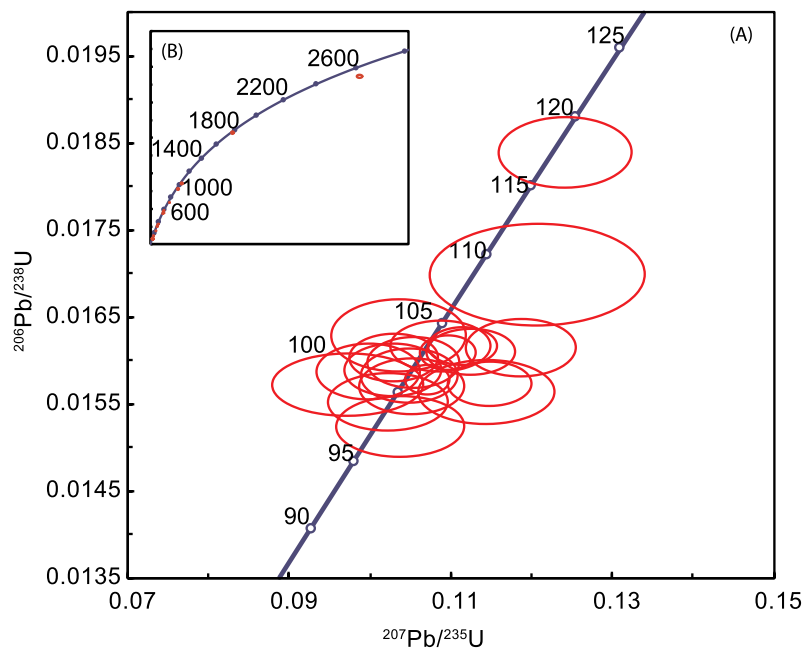

Fig. 7. U-Pb c oncordia $\mathrm{f}$ or all Cretaceous g rains ( A) and all g rains ( B). Error ellipses are $1 \sigma$.

commonly 1:2. The second group of zircons is highly variable and encompasses a wide range of morphologies more typical of a detrital zircon sample with contrasting provenance. Grains typically exhibit

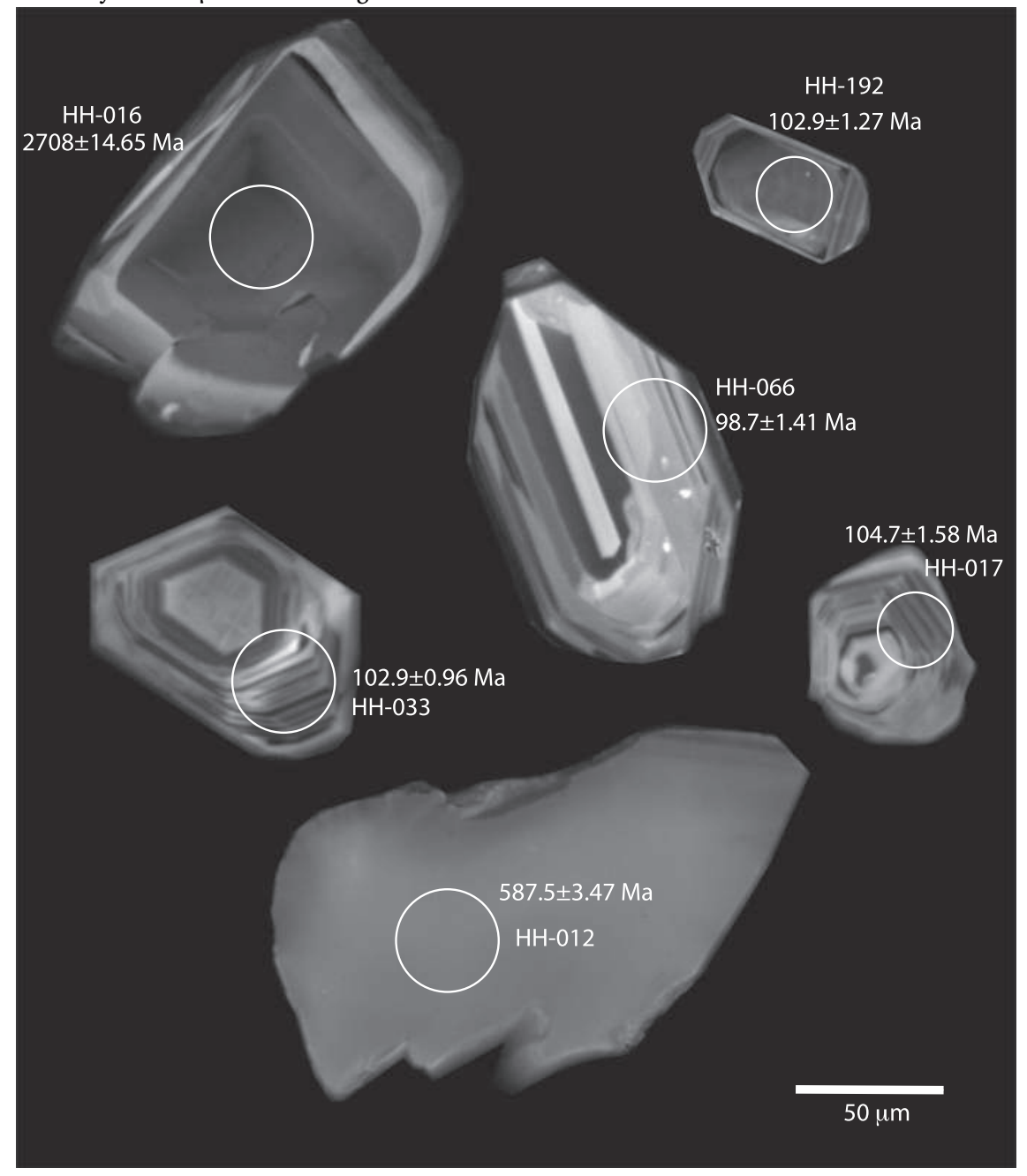

Fig. 6. Cathodoluminescence images of the internal zoning patterns of detrital zircons extracted from the Hard Hill locality. White circles represent the locations of in situ analyses with individual ages noted. Cretaceous zircons (group one) are a distinctive population exhibiting fine magmatic zoning and euhedral shapes. Group two zircons were highly variable in age, texture, size and shape. 


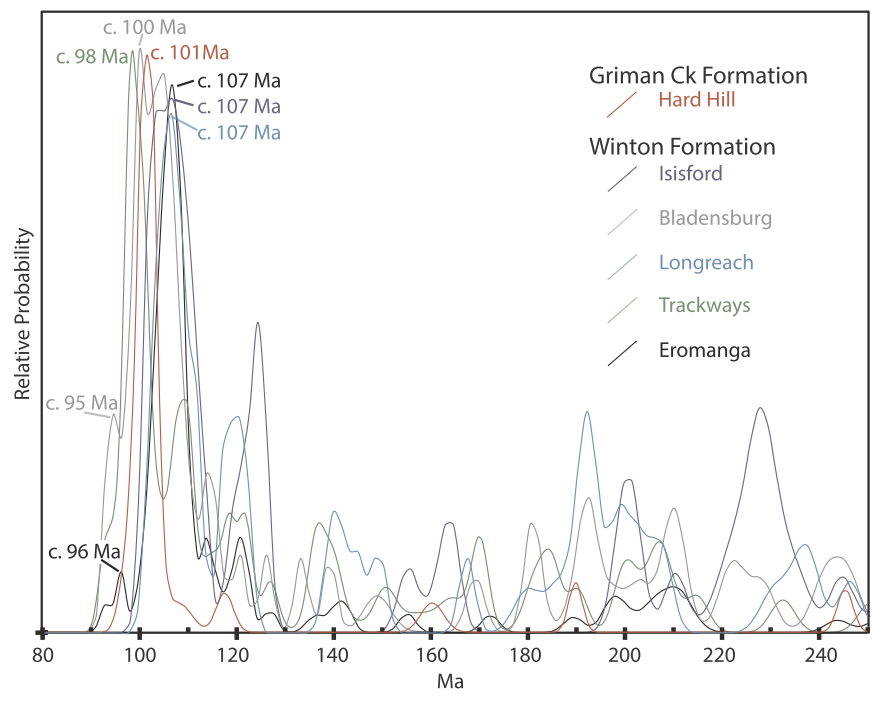

Fig. 8. Relative probability age curves for detrital zircon spectra $(<250 \mathrm{Ma}$, $n=28$ ) of the Griman Creek Formation (this study) and the Winton Formation (Tucker et al., 2013).

degrees of rounding, from near spherical to sub angular and are often fragmentary. Cathodoluminescence imaging reveals highly variable textures, such as core rim textures including xenocrystic cores; subdued, blurred or absent zoning suggestive of metamorphism; recrystallization textures and also magmatic oscillatory zoning (Fig. 6). The lengths are highly variable, with grains from $40 \mu \mathrm{m}$ to over $200 \mu \mathrm{m}$. The small size of some zircons prevented analysis by the LAM-ICPMS as $\sim 25 \mu \mathrm{m}$ is the smallest beam size that still provided acceptable precision. Forty-three analyses gave a total age range from c. 2700-97 Ma. Twenty-five group one zircons were analysed, all of which give ${ }^{238} \mathrm{U} /{ }^{206} \mathrm{~Pb}$ ages between 117 and $97 \mathrm{Ma}$ (see Fig. 7 for U-Pb Concordia plots). The youngest detrital grain is $96.9 \pm 1.49 \mathrm{Ma}$. The youngest set of grains were calculated as $98.08+1.1 /-2$ Ma with a $95 \%$ confidence. The weighted average of the three youngest grains in the population is $98.3 \mathrm{Ma} \pm 1.7 \mathrm{Ma}$. The 'tuffzirc' age calculation is $99.65+$ $0.45 /-2.75$ Ma with a $96.9 \%$ confidence from 6 grains. The youngest graphical peak in the population is $101 \mathrm{Ma}$ (Fig. 8).

\section{Vertebrate diversity}

We present a brief overview of the vertebrate palaeontology here; a comprehensive revision of the vertebrate fauna, along with taxonomic justifications (where applicable), is given in Bell et al. (supplementary data) and is summarised in Table 1. The following institutional abbreviations are used: AM F - Australian Museum, Sydney, New South Wales, Australia, NHMUK - Natural History Museum, London, United Kingdom, LRF - Australian Opal Centre, Lightning Ridge, New South Wales, Australia. QM F - Queensland Museum, Brisbane, Queensland, Australia.

\subsection{Fishes}

Although significant collections of undescribed fish remains are curated at the Australian Opal Centre and the Australian Museum (Molnar, 1980c; Dettman et al., 1992; see also Smith, 1999), documented marine teleosts consist only of rare aspidorhynchid scales (Fig. 9H; Kear and Hamilton-Bruce, 2011) and extremely rare lamniform chondrichthyans (Smith, 1999; Kear and Hamilton-Bruce, 2011) based on two isolated teeth (Fig. 9A-E; Bell et al., supplementary data). By contrast, dipnoans are particularly diverse (Fig. 9F, G, I, J), being represented by numerous isolated tooth plates pertaining to a variety of ceratodontiformes (Ceratodus diutinus, Metaceratodus wollastoni, Neoceratodus forsteri) and described by Chapman (1914), Kemp and Molnar
(1981) and Kemp (1993, 1997a, 1997b).

\subsection{Turtles, crocodylomorphs, plesiosaurs and pterosaurs}

Isolated testudine elements (shell fragments, limb elements, vertebrae) are among the most commonly recovered vertebrate remains. Only one taxon has been named: a possible meiolaniform, Spoochelys ormondea, based on a superbly preserved skull (LRF-TH450; Fig. 10A, B) and assigned postcranial elements (Smith and Kear, 2013). Smith (2010) identified at least two indeterminate chelids (Fig. 10C) and Smith (2009) mentioned up to two additional meiolaniid-like turtles from the GCF; however, the latter have yet to be formally described.

Molnar (1980b) and Molnar and Willis (2001) recognise at least two crocodyliforms; a conical-toothed ?eusuchian, based on a partial maxilla (AM F15818; originally described as the dentary of 'Crocodylus (Bottosaurus) selaslophensis' by Etheridge, 1917; Fig. 10H, I) and an indeterminate broad-snouted, ziphodont mesoeucrocodylian (Fig. 10J, K). A re-analysis of AM F15818 and other GCF crocodyliform material is currently in progress by one of us (LH) and will be presented elsewhere.

Plesiosaurs are relatively abundant, represented most commonly by isolated teeth (Fig. 10D, E; Kear, 2006; Kear et al., 2006). Rare postcranial remains-not yet formally reported or described from Lightning Ridge-are held in the Australian Opal Centre collections, and have also been described from the GCF exposed near Surat in southeastern Queensland (Kear, 2006). Following Benson and Druckenmiller (2014), all of this material is best referred to Leptocleidia or a leptocleidid-like taxon/taxa (Kear, 2016).

Anhanguerian pterosaurs were recently described by Brougham et al. (2017) based on two isolated tooth crowns (Fig. 10F, G) although two purported limb elements have also been figured but not described (Smith, 1999).

\subsection{Dinosaurs}

Dinosaurs are most commonly represented by isolated ornithopod remains (Molnar, 1980a, 1996; Molnar and Galton, 1986; Agnolin et al., 2010). Fulgurotherium australe, initially described as a theropod by von Huene (1932) and corrected by Molnar (1980a), is now regarded as a nomen dubium (Agnolin et al., 2010). Molnar and Galton (1986) and Molnar (1996) assigned 'Fulgurotherium' and other isolated material to two indeterminate taxa of small-bodied ornithopod ('hypsilophodontids' of those authors) (Fig. 11A-E). A recent revision of the ornithopod diversity, based on craniodental remains from the GCF, revealed the presence of at least two (possibly three) 'basal' ornithopods, including Weewarrasaurus pobeni (Bell et al., 2018). Bell et al. (supplementary data) described a new iguanodontian, Fostoria dhimbangunmal, based on parts of four individuals collected from a single mine at the Sheepyard locality, which collectively represent the most complete remains of any dinosaur from the state of New South Wales. 'Muttaburrasaurus-like' teeth (Fig. 11F, G) described by Molnar (1996) and Bell et al. (2018) and a large scapula figured and mentioned by Long (1998, p.123) probably also pertain to Fostoria. A long bone fragment (AM F102462), referred to by Long (1998) as a plesiosaurian propodial but refuted by Kear (2006), in fact derives from the same excavation as Fostoria and likely pertains to that taxon. A possible ankylopollexian is represented by a fused basioccipital-basisphenoid (Bell et al., 2018), bringing the total number of ornithopods to at least four. Possible large ornithopod tracks in the roof of one mine were mentioned by Thulborn $(1990,1994)$ although the originals appear to have been obliterated by rockfall and are no longer available for study. The only other ornithischian dinosaur currently recognised is an indeterminate ankylosaurian identified on the basis of a single characteristic osteoderm (Bell et al., 2017; Fig. 11J, K).

Saurischian dinosaurs are represented by the isolated teeth of titanosauriform sauropods (Molnar and Salisbury, 2005; Fig. 11H, I); these teeth, held at the Australian Opal Centre and the Australian Museum 
Table 1

Vertebrate fauna of the Griman Creek Formation, Lightning Ridge, New South Wales.

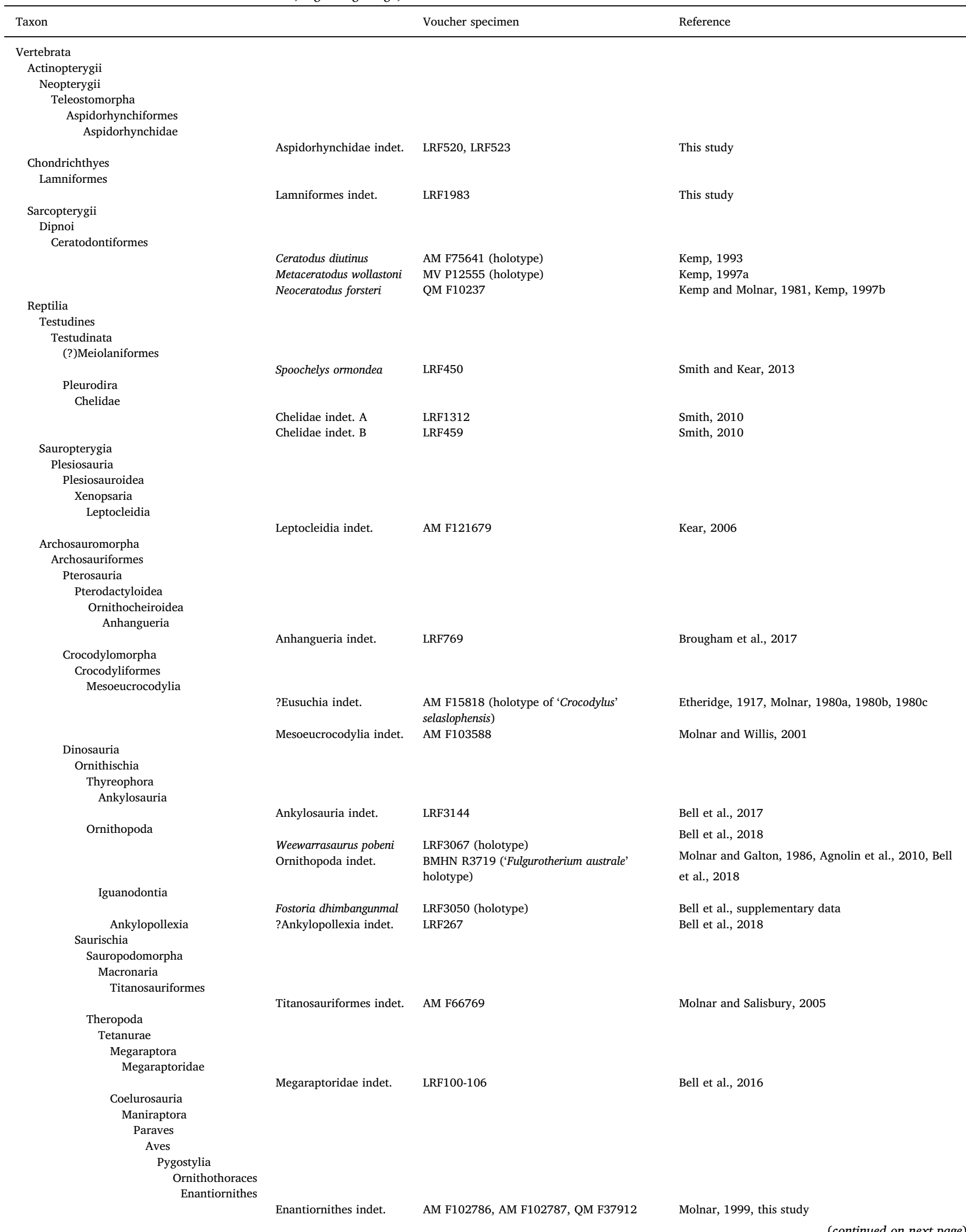


Table 1 (continued)

\begin{tabular}{|c|c|c|c|}
\hline Taxon & & Voucher specimen & Reference \\
\hline \multicolumn{4}{|l|}{ Therapsida } \\
\hline \multicolumn{4}{|l|}{ Theriodontia } \\
\hline \multicolumn{4}{|l|}{ Cynodontia } \\
\hline \multicolumn{4}{|l|}{ Mammalia } \\
\hline \multicolumn{4}{|l|}{ Australosphenida } \\
\hline & Kollikodon ritchiei & AM F96602 (holotype) & Flannery et al., 1995, Pian et al., 2016 \\
\hline \multicolumn{4}{|l|}{ Monotremata } \\
\hline & Steropodon galmani & AM F66763 (holotype) & Archer et al., 1985 \\
\hline & Monotremata indet. & AM F118621 & Clemens et al., 2003; T. Rich in Poropat et al., 2018 \\
\hline
\end{tabular}

are currently under study. Molnar (2011) has also reported non-opalised, indeterminate sauropod bones (an ischium and a possible neural arch fragment, the latter of which is unlikely to belong to a sauropod [S. Poropat pers. comm., 2018]) from exposures of the GCF near Surat in south-eastern Queensland. The partial skeleton of an indeterminate megaraptorid theropod (Bell et al., 2016; Fig. 11L, M) and other isolated megaraptorid and indeterminate remains (Smith Woodward, 1910; von Huene, 1932; Molnar et al., 1981; White et al., 2013) constitute the limited theropod fossil record. Two taxa named by von Huene (1932) based on isolated material, Rapator ornitholestoides and Walgettosuchus woodwardi, are now widely regarded as nomina dubia (Molnar, 1990; Agnolin et al., 2010; Bell et al., 2016). Additional nonavian theropod postcranial remains at the Australian Opal Centre and Australian Museum are under study by one of us (TB) and promise to yield important new information on the diversity of this group in the GCF.

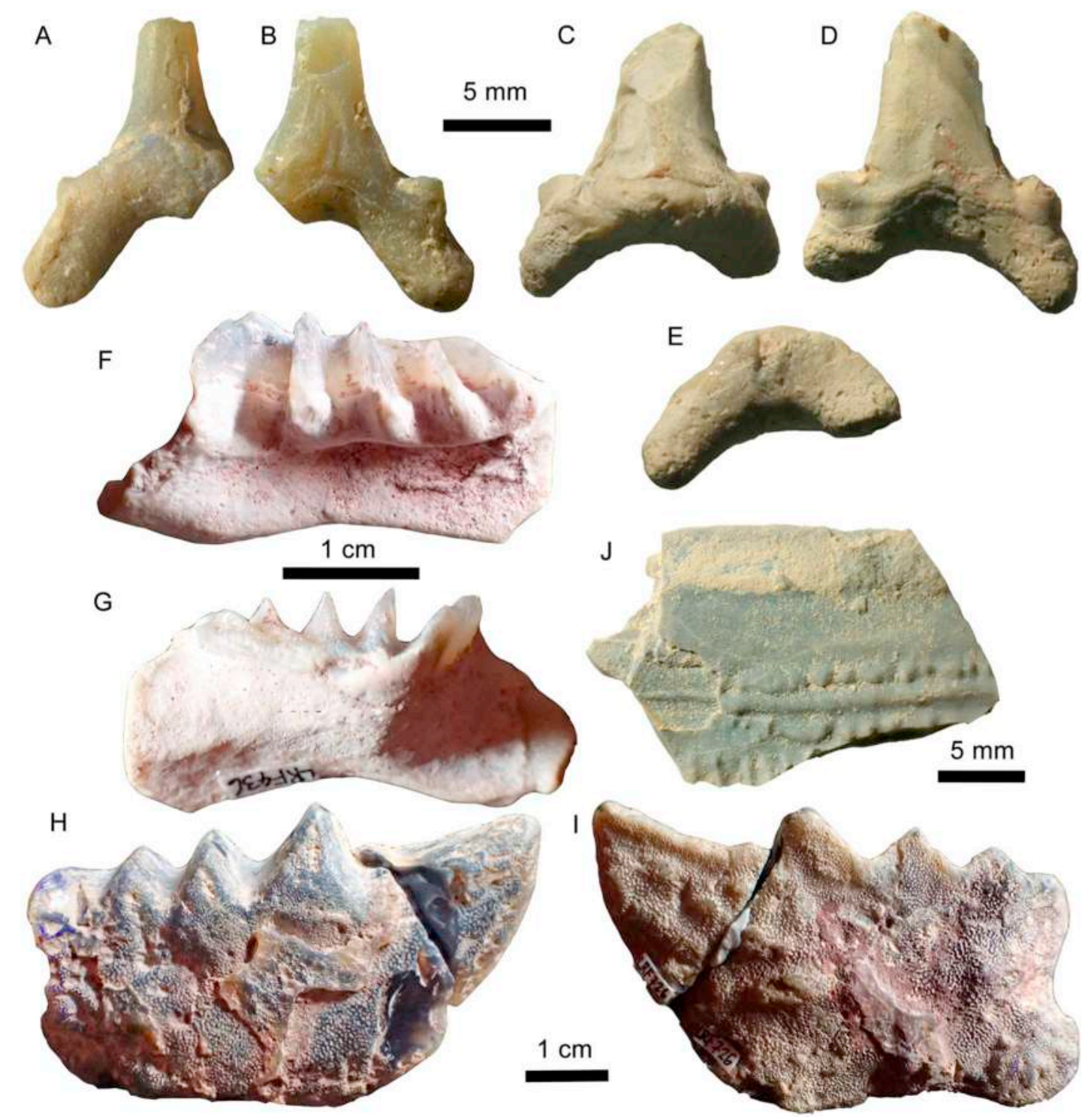

Fig. 9. Chondrichthyes and Osteichthyes. (A-E) Lamniform indet. teeth (A-B, LRF 1983; C-E, LRF 1875) in lingual (A, C), labial (B, D), and basal (E) views; F-G, Neoceratodus forsteri lower toothplate (LRF 436) in occlusal (F) and ventral (G) views; (H-I) Metaceratodus wollastoni upper toothplate (LRF 726) in occlusal (H) and ventral (I) views; (J) Ichthyodectiformes cf. Richmondichthyes (LRF 520) scale in lateral (external) view. 
A
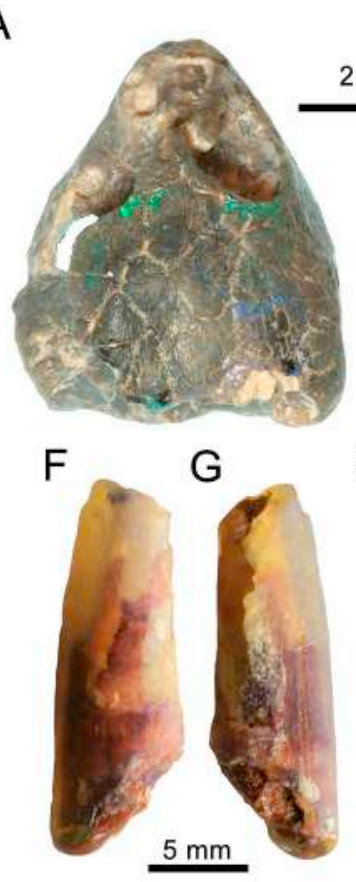

B

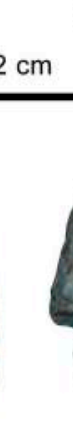

$\mathrm{H}$

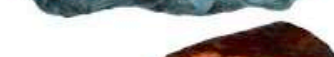

C

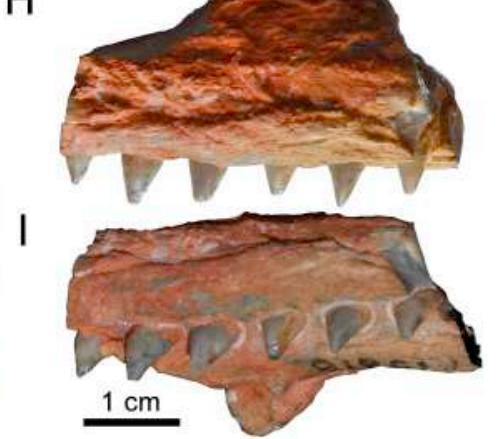

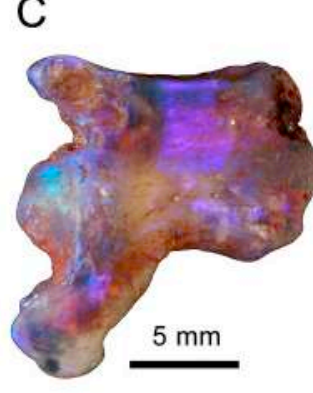
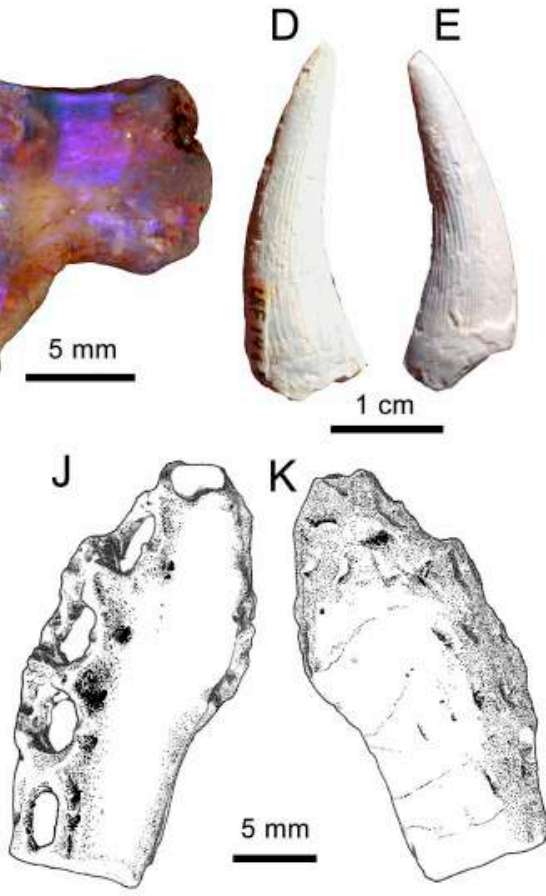

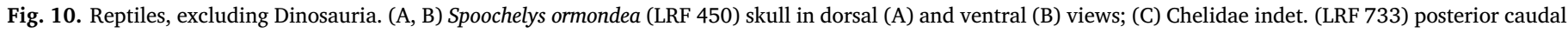

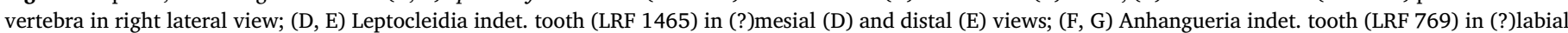

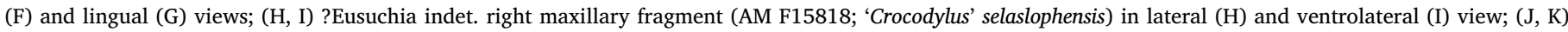

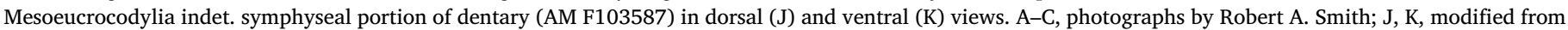
Molnar and Willis (2001).

Molnar (1999) described several avian bones that he identified as the distal tibiotarsi of non-enantiornithine ornithothoracines (Fig. 12A-T). However, a far richer global record of fossil avians than was first available to Molnar (1999) now suggests that these specimens are in fact enantiornithine distal femora (J. O'Connor pers. comm., 2017).

An enigmatic bicuspate tooth may represent a non-mammalian synapsid (Clemens et al., 2003) although a notosuchian crocodyliform or a dryolestid cladotherian mammal could not be ruled out by those authors. Most recently, T. Rich (in Poropat et al., 2018) has suggested the tooth belongs to a large monotreme. Other mammals are represented by extremely rare, but beautifully preserved craniodental remains. Two taxa are known: Kollikodon ritchei is an australosphenidian and was recovered as the sister taxon to Monotremata (Flannery et al., 1995; Musser, 2003, 2006; Pian et al., 2016; Fig. 13A). Steropodon galmani (Fig. 13B) is accepted as a true monotreme on the line to Ornithorhynchidae (Archer et al., 1985; Musser, 2006; Phillips et al., 2009; Pian et al., 2016). Kollikodon and Steropodon were among the largest known Cretaceous mammals, perhaps rivalling in size some of the smaller dinosaurs present in the area (Archer et al., 1985).

Although this review is restricted to vertebrates, we also note the abundant invertebrate record, which includes freshwater crayfish (Smith, 2009), thiarid (Hamilton-Bruce et al., 2004), viviparid (Hamilton-Bruce et al., 2002; Hamilton-Bruce and Kear, 2006), and succineid gastropods (Hamilton-Bruce and Kear, 2010) as well as hyriid (Hocknull, 2000) and unionid bivalves (Newton, 1915; McMichael, 1956; Hocknull, 1997; Kear and Godthelp, 2008), and rare foraminiferans (Scheibnerova, 1984). Fossil microbes (including a variety of bacteria, slime moulds, and fungi) are reputedly synchronous with opal formation and may have been incorporated at the same time as the sediments were being accumulated (Watkins et al., 2011).

\section{Discussion}

\subsection{Provenance and age}

The detrital zircon age spectra from Hard Hill (Griman Creek Formation) indicate multiple sedimentary sources and are similar to provenance described by Tucker et al. (2016) to the north (see Fig. 8 and raw data in Supplementary material). The pre-Cambrian detrital zircon component is likely to correspond to source rocks from central Australia, Broken Hill, potentially including the Delamerian Orogen (see Glen, 2013 and Tucker et al., 2016). A significant component of the age spectra (Palaeozoic-Mesozoic) has an eastern Australian provenance. Detrital grains of c. 350-315 Ma and c. $250 \mathrm{Ma}$, suggest a contribution from the New England Orogen to the east (see Glen, 2013 and Tucker et al., 2016). The source for the Cretaceous detrital zircons lies further to the east again, from a now mostly submerged Mesozoic arc preserved in Zealandia (Mortimer et al., 2017). This continental arc ran along the Palaeo-Pacific Gondwana margin from Queensland (Whitsundays region; e.g. Tulloch et al., 2010, Tucker et al., 2016), through the Lord Howe Rise, (Tulloch et al., 2009) to New Zealand (e.g. Milan et al., 2016, 2017). The Queensland component of the arc was originally described as a large igneous province (Bryan et al., 1997); however, subsequent studies suggest it is a continuation of the Gondwana margin arc undergoing arc related extension (Tulloch et al., 2010; Tucker et al., 2016).

Cretaceous ultra-distal ash falls probably originated in the interior of Australia, carried by seasonal winds (Barham et al., 2016, 2018). Cretaceous detrital zircons interpreted to have undergone significant transportation within an eruption plume emanating from the active continental arc on the Palaeo-Pacific margin of Gondwana were found as far west as Western Australia in the onshore Bight Basin (Barham et al., 2016, 2018). This conclusion was based on limited abrasion of Cretaceous zircon grains, contrasting to the older detrital components, and overlapping zircon $\mathrm{U}-\mathrm{Pb}-\mathrm{Hf}$ isotope ratios and trace element 

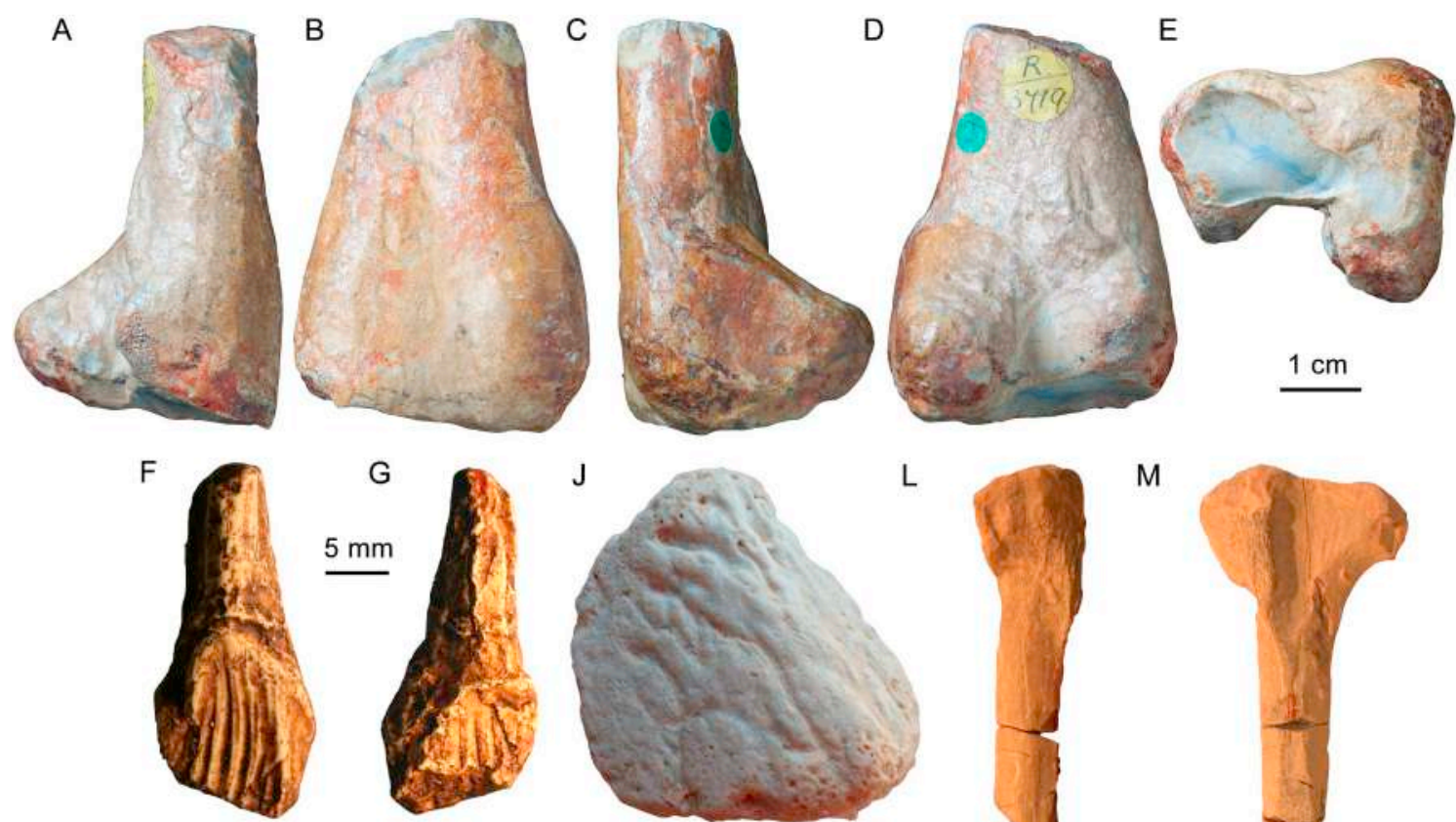

$\mathrm{H}$

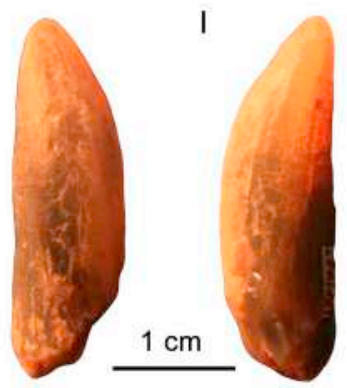

$\mathrm{K}$
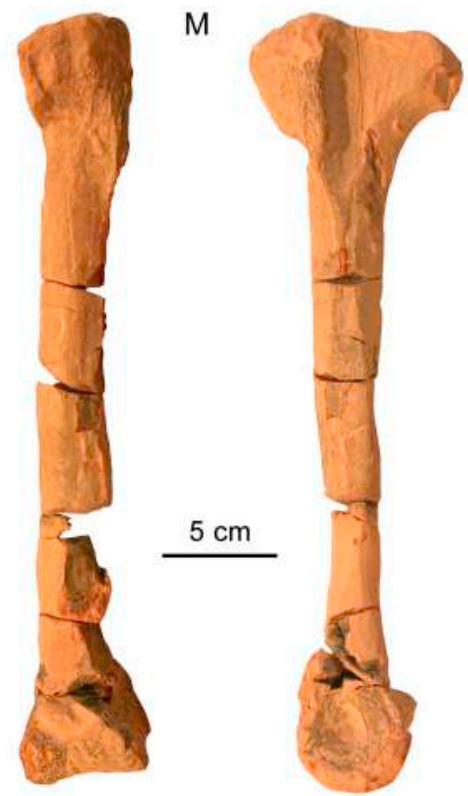

Fig. 11. Non-avian Dinosauria. (A-E) Iguanodontia indet. (NHMUK R3719; holotype of 'Fulgurotherium australe') distal left femur in (A) medial, (B) cranial, (C) lateral, (D) caudal, and (E) distal aspects. (F, G) Iguanodontia indet. (QM F14421, cast of AM F112860) maxillary tooth in (F) labial and (G) lingual aspects. (H, I) Titanosauriformes indet. (LRF 1702) tooth crown in (H) labial and (I) lingual aspects. (J, K) Ankylosauria indet. (LRF 3144) lateral osteoderm in (J) dorsal and (K) anterior views. (L, M) Megaraptoridae indet. (LRF 100-106) left metatarsal III in (L) cranial and (M) lateral aspects. Photos in A-E by S. Poropat; J, K modified from Bell et al. (2018); L, M modified from Bell et al. (2016).
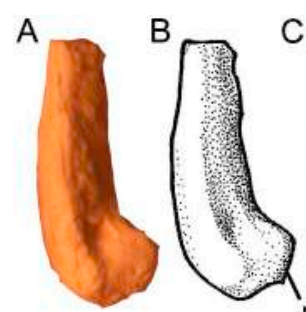

K

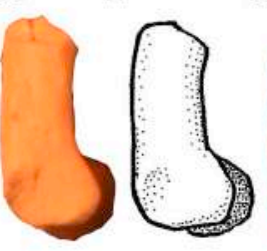

C

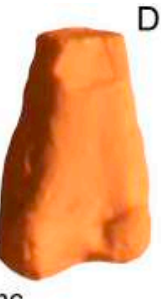

$\mathrm{M}$
D

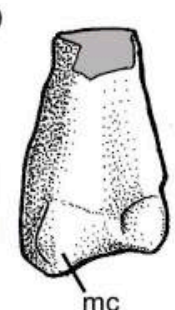

N

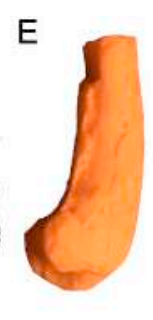

0

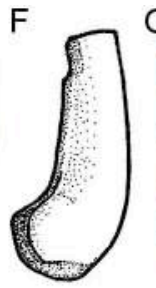

P

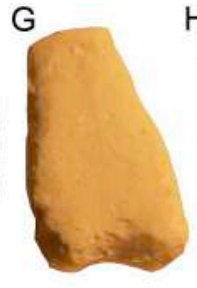

Q

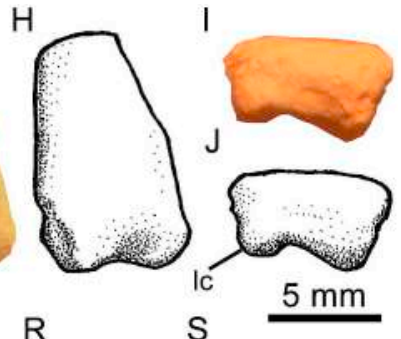

R

S

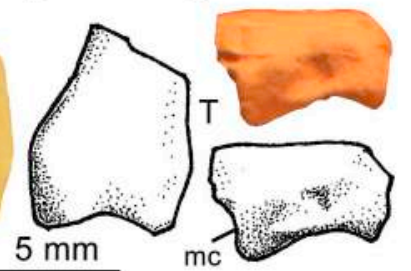

Fig. 12. Avian distal femora from the Griman Creek Formation. (A-J) Enantiornithes indet. (QM F36997; cast of AM F102786), distal end of right femur in (A, B) medial, (C, D) caudal, (E, F) lateral, (G, H) cranial, and (I, J) distal aspects. (K-T) Enantiornithes indet. (QM F36998; cast of AM F102787), distal end of left femur in $(\mathrm{K}, \mathrm{L})$ lateral, (M, N) caudal, (O, P) medial, (Q, R) cranial, and (S, T) distal aspects. Grey denotes broken surfaces. lc, lateral condyle; mc, medial condyle. 


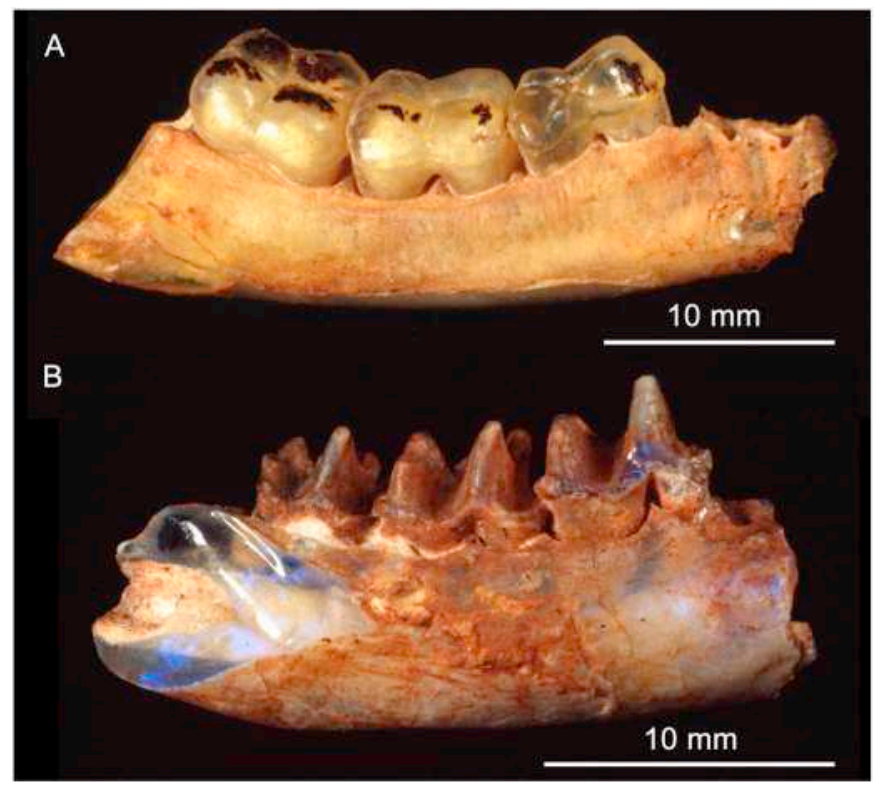

Fig. 13. Mammalia from the Griman Creek Formation. (A) Kollikodon ritchiei (AM F96602) holotype partial right dentary in lateral view. (B) Steropodon galmani (AM F66763) holotype partial right dentary in lateral view. Photos: Robert A. Smith.

signatures with the Cretaceous source rocks (Barham et al., 2016, 2018).

Similar characteristics can be seen in the zircon populations at Hard Hill. We observe a euhedral Cretaceous zircon population that overlap in $\mathrm{U}-\mathrm{Pb}$ ages with the source continental arc to the east, contrasting remarkably to a population of older and abraded detrital zircons sourced from the Gondwana continental interior. Given distal ashfalls are reported to have occurred in the interior of Australia, we interpret the Cretaceous zircon population from the 'waxy band' to represent reworked airfall tuffs that fell in the Surat Basin catchment.

The XRD analysis of the 'waxy band' revealed a bentonite-like composition, with the main clay species consisting of montmorillonite and kaolin (Supplementary material). Montmorillonite is a common alteration product of glassy volcanics, and could support our interpretation of a volcanogenic source for the 'waxy band'. Kaolin minerals may be the product of chemical weathering of feldspars. Other minerals confirmed included quartz, illite and possibly vermiculite.

The GCF preferred maximum depositional age range is early to midCenomanian, with a range of 100.2-96.6 Ma. It should be stressed that this age range relates to the available exposures (and its fauna) around Lightning Ridge and may or may not be relevant to significantly deeper parts of the GCF at Lightning Ridge (up to $200 \mathrm{~m}$ depth based on core samples; Hawke and Cramsie, 1984) or to exposures of the GCF in other parts of the Surat Basin. Fission-track dating of two zircons from drill core samples in the eastern (Queensland) margin of the Surat Basin retrieved ages of $\sim 99$ and $\sim 107 \mathrm{Ma}$, respectively (Raza et al., 2009). Although one of these falls within our plotted range (see below), the low sample size urges caution when considering the actual age of the deposits. Our range (100.2-96.6 Ma) is based on a combination of the following maximum depositional age calculations and their error bars: youngest set of grains, weighted average of three youngest grains and the 'tuffzirc' method (Fig. 14). We did not utilise the weighted mean average calculations that were employed by Tucker et al. (2013), due to a lack of Th and $U$ trace element data for our samples. However, these zircons have had no apparent geological overprints or complexity based on their textures and geological history. Furthermore, for the Winton Formation samples (Tucker et al., 2013), weighted average $(+3)$ age calculations are in all cases identical to their weighted mean average $(Y C 2 \sigma(+3)$ and YC3 $\sigma(+3))$ age calculations, although the error bars of the latter are far greater. Based on these observations our weighted average calculations are likely to be similar to a weighted mean average age calculation.

The age range of Cretaceous detrital zircons sampled within the adjacent contemporaneous Eromanga Basin span 140-90 Ma (Veevers et al., 2016). Because volcanic activity is known to have persisted past the calculated maximum depositional age, there is a potential for the youngest single grain to be significant in that it might mark the actual depositional age of the GCF (c. $97 \mathrm{Ma}$ ). The maximum depositional age and the youngest single zircon ages are within error, so for this to be confirmed, further data would be needed. Traditionally, the youngest single detrital zircon grain age is treated with caution due to it being a single data point (see Dickinson and Gehrels, 2009; and discussion in Tucker et al., 2013).

To enable a comparison of the fauna of the GCF with the well-studied Winton Formation nearly $1000 \mathrm{~km}$ to the north, we plotted all of the aforementioned calculated maximum depositional ages including error bars (Fig. 14). On comparing the maximum depositional ages for the Winton Formation to the GCF, the latter generally sits between (with some very minor overlap) the older Albian (Isisford and Long reach sites) and younger Cenomanian to Turonian (Lark Quarry, Bladensburg and Eromanga sites).

\subsection{Palaeoecology}

The Griman Creek Formation comprises a rich vertebrate fauna of aspidorhynchid teleosts, lamniform chondrichthyans, several dipnoans, chelid and possible meiolaniform turtles, anhanguerian pterosaurs, titanosauriform sauropods, megaraptoran theropods, ankylosaurians, non-iguanodontian and iguanodontian ornithopods, crocodyliforms, enantiornithine birds, and both stem and true monotremes (Table 1). This revised list confirms the Griman Creek Formation as one of the richest terrestrial vertebrate faunas from the Mesozoic of Australia (Dettman et al., 1992; Smith, 2009; Meakin, 2011).

In order to infer the palaeoecology of the Griman Creek Formation at Lightning Ridge, the fossil record needs to be discussed in light of the new sedimentological data presented in this study. It is important to note that the distribution of vertebrates (and invertebrates) in the opal fields around Lightning Ridge is non-uniform. For example, rare taxa (e.g. chondrichthyans, aspidorhynchids) are known from only a handful of localities, which has implications for possible local influences on faunal composition. A quantitative assessment of the fauna distribution in the GCF is beyond the scope of this study and will be presented elsewhere. Although a detailed faunal comparison between the GCF and the vertebrate-bearing units of the Eromanga, Otway, and Gippsland basins is also beyond the scope of this paper, several outstanding features are notable. At a high taxonomic level, the composition of the GCF vertebrate fauna compares favourably with other mid-Cretaceous terrestrial deposits in eastern Australia-namely, the Winton Formation in Queensland to the north and the Eumeralla Formation (including the former 'Wonthaggi Formation') in Victoria. Notable distinctions between the dinosaurian faunas exist, however. In particular, despite exhaustive fieldwork in the region over the past three decades, sauropod and iguanodontian (i.e., exclusive of Elasmaria) material is absent from the Victorian deposits (Benson et al., 2012; Poropat et al., 2018). Poropat et al. (2016) convincingly argued that the absence of sauropods reflected the environmental preferences of these animals: sauropods are unknown from palaeolatitudes higher than $66^{\circ}$ north or south and were less diverse at high latitudes compared to mid-low latitudes during the Cretaceous, suggesting a preference towards warmer climes (Poropat et al., 2016). Thus, at a palaeolatitude of $\sim 60^{\circ} \mathrm{S}$, the GCF titanosauriforms represent the southern-most occurrences of these animals in Australia and are close to the southern limit for Cretaceous sauropods in general (Cerda et al., 2012). Although several incomplete postcranial elements have been described from the northern part of the Surat Basin (Molnar, 2011), the limited sample of sauropod material from the GCF 


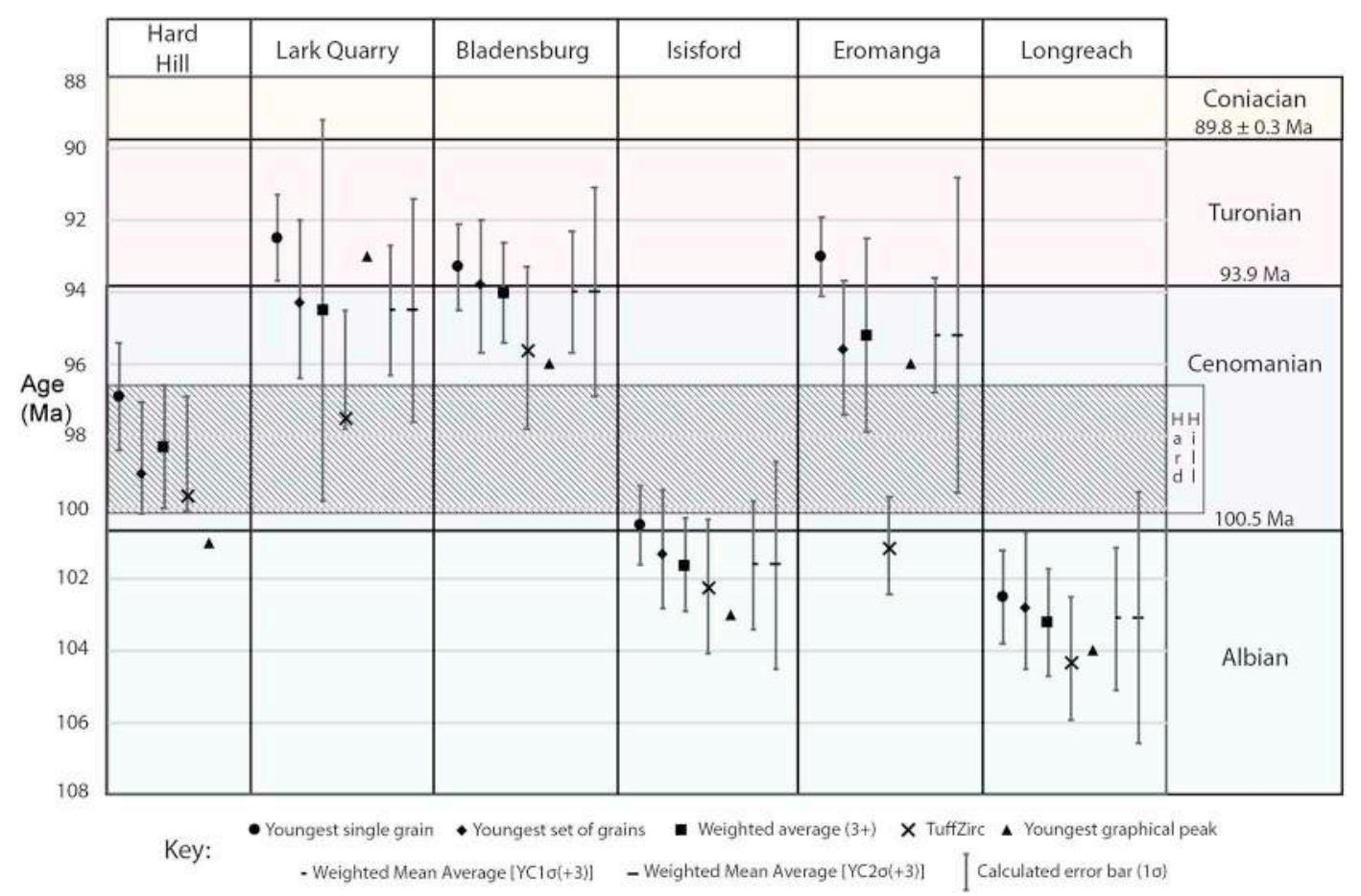

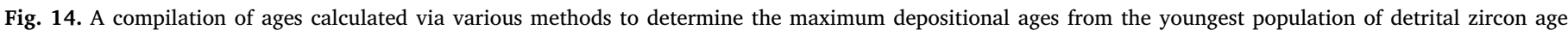

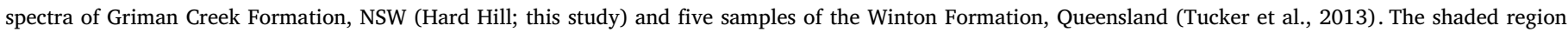

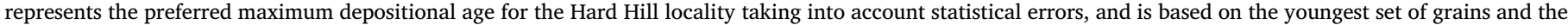
weighted average (+3). Stages were taken from the International Chronostratigraphic Chart v. 2017/02 (Cohen et al., 2013; updated).

at Lightning Ridge (all teeth) prevents further comparisons of sauropod diversity/affinities between the GCF and the various mid-Cretaceous sauropod-bearing units in Queensland (Hocknull et al., 2009; Poropat et al., 2016, 2017).

Similarly, large-bodied iguanodontians (represented by teeth and postcranial remains from the GCF; Muttaburrasaurus from the Allaru Mudstone and Mackunda Formation in Queensland [Bartholomai and Molnar, 1981; Molnar, 1996], and; trackways from the Winton Formation [Thulborn and Wade, 1984; Romilio and Salisbury, 2011]) are conspicuously absent from Victoria. Whether these apparent differences in relative abundance and/or taxonomic distribution are driven by taphonomic or real biological/environmental factors is unclear at this stage; however, given that other large-bodied forms (e.g., Benson et al., 2012) are known from the upper Strzelecki Group and Eumeralla Formation, and the abundance of iguanodontians in other 'mid'-Cretaceous localities on a global scale (e.g., Norman, 2004), the absence of largebodied Iguanodontia from Victoria is at least thought-provoking. Furthermore, as argued by Poropat et al. (2016), the absence of sauropods from the Aptian-Albian of Victoria likely reflects their exclusion from the Australian-Antarctic rift valley due to its cool climate and it is tenable that similar limitations excluded some iguanodontians.

In contrast to the upper Strzelecki Group, and the Eumeralla and Griman Creek formations, the Winton Formation is depauperate in small-bodied bipedal neornithischians ('basal ornithopods'), which are currently represented by a single tooth (Hocknull and Cook, 2008), although trackway evidence at the famous Lark Quarry 'stampede' provides additional evidence for these animals (Thulborn and Wade, 1984; Romilio et al., 2013; Thulborn, 2017). Although some small ornithopod material from Victoria was initially referred to Fulgurotherium australe (e.g. Rich and Rich, 1989; Rich and Vickers-Rich, 1999), the holotype of this taxon-which comes from the GCF-is only identifiable as a non-iguanodontian ornithopod (sensu Madzia et al., 2018) and, as previously noted by Rich and Rich (1989), renders confident referral of the Victorian material to this taxon highly doubtful. Moreover, some of the Victorian femora (including some of those originally referred to $F$. australe) are probably attributable to one or more of the named taxa known solely from cranial (Atlascopcosaurus loadsi, Leaellynasaura amicagraphica, Qantassaurus intrepidus) and non-overlapping postcranial material (Diluvicursor pickeringi) from the same deposits (Rich and Rich, 1989; Rich and Vickers-Rich, 1999; Herne et al., 2018). Regardless of the low-level taxonomy of these specimens, the preponderance of smallbodied bipedal neornithischians ('hypsilophodontids' of Rich and Rich, 1989; Rich and Vickers-Rich, 1999) in both the GCF and at the Victorian localities is notable.

Although megaraptorans are present in the Griman Creek, Eumeralla (including the 'Wonthaggi Formation' in the upper Strzelecki Group) and Winton formations (Smith et al., 2008; Hocknull et al., 2009; Benson et al., 2012; White et al., 2013, 2015; Bell et al., 2016), none of the purported diversity of non-megaraptoran theropods from the Eumeralla Formation (Benson et al., 2012 and references therein) has yet been reported from either the Griman Creek or Winton formations. Similarly, the controversial presence of ceratopsians in the upper Strzelecki Group (Rich and Vickers-Rich, 2003; Rich et al., 2014) has not been confirmed elsewhere in Australia.

Where observable, genus- and species-level distinctions between the three regions (central Queensland, Lightning Ridge, southern Victoria) are apparent within the dipnoan, testudinatan, and mammalian faunas; however, such species-level resolution is currently unavailable for all other taxonomic groups known from the GCF. It should also be recognised that mammals have yet to be described from the Winton Formation, which can be safely attributed to a preservation/collection bias rather than a true absence. Only the dipnoan Metaceratodus wollastoni is found across the entire geographic (and temporal) range, including the Griman Creek, Eumeralla, and Winton formations (Kemp, 1991, 1997a; Kemp and Berrell, 2013). Rare marine occurrences of this taxon in the Mackunda Formation near Kyuna (Queensland; Kemp, 1991) and the Doncaster Member (Wallumbilla Formation) at White Cliffs (New South Wales; White, 1926) are probably the result of hydraulic transport of carcasses from their original freshwater habitats (Kemp, 1991). Ceratodus diutinus is also present in the GCF and the 
Toolebuc Formation in central Queensland (Kemp, 1993).

\section{Conclusions}

The vertebrate fauna from the Griman Creek Formation (GCF) at

- Lightning Ridge represents one of the most diverse, yet understudied, from the entire Mesozoic of Australia. Palaeoecological interpretation based on observed exposures suggest a low-energy, coastal lowland to lagoonal ecosystem with significant fluvial sediment discharge.

- Although the local stratigraphy around Lightning Ridge cannot at this stage be tied into the regional stratigraphy of the GCF, the main fossil-bearing unit (represented by the Wallangulla Sandstone) accumulated relatively rapidly, supported by high sediment supply and limited $(\sim 30 \mathrm{~m})$ vertical distribution.

- New maximum depositional ages (100.2-96.6 Ma) reported here, derive from a bentonite-rich layer immediately overlying one of the main fossil-bearing horizons, indicating an early to midCenomanian age (rather than Albian) for the Lightning Ridge fauna.

- The Lightning Ridge fauna is temporally straddled by several of the major dated localities from the Winton Formation, representing an important advance in our understanding of the chronostratigraphy and palaeoecology of eastern Australia during the mid-Cretaceous.

- Although taxonomic resolution is poor at this stage, the vertebrate fauna appears 'intermediate' in composition between the northerly faunas of the Winton Formation and the more polar-influenced fauna of the Australian-Antarctic rift valley.

- Given the limited low-level taxonomy available for most of the GCF vertebrate fauna and the large (or poorly constrained) time frames represented by the various terrestrial vertebrate-bearing units in eastern Australia, the present evaluation is best regarded as a starting point from which better-informed comparisons can be made based from future discoveries.)

\section{Acknowledgements}

We are indebted to the miners at Lightning Ridge who have provided access to mines, donated specimens, shared knowledge, and spent countless hours searching for opals and fossils. Special thanks to Jenni Brammall (Australian Opal Centre, Lightning Ridge), Matt McCurry (Australian Museum), Scott Hocknull (Queensland Museum) for access to their fossil collections; Blake Larter for CL imaging the zircons; Rosanna Murphy for assistance during U-Pb analyses, and; Robert A. Smith and Stephen Poropat for selected specimen photographs. Insightful reviews from Ryan Tucker, Stephen Poropat, and Howard Falcon-Lang (editor) greatly improved the final version of this manuscript. We acknowledge the Yuwaalaraay, Yuwaalayaay and Gamilaraay custodians of country in the Lightning Ridge district, and pay our respects to Elders past and present. This research was funded by an Australian Research Council Discovery Early Career Researcher Award (project ID: DE170101325) to PRB.

\section{Appendix A. Supplementary data}

Supplementary data to this article can be found online at https:// doi.org/10.1016/j.palaeo.2018.11.020.

\section{References}

Agnolin, F.L., Ezcurra, M.D., Pais, D.F., Salisbury, S.W., 2010. A reappraisal of the Cretaceous non-avian dinosaur faunas from Australia and New Zealand: evidence for their Gondwanan affinities. J. Syst. Palaeontol. 8 (2), 257-300.

Archer, M., Flannery, T.F., Ritchie, A., Molnar, R.E., 1985. First Mesozoic mammal from Australia - an early Cretaceous monotreme. Nature 318, 363-366.

Barham, M., Kirkland, C.L., Reynolds, S., O'Leary, M.J., Evans, N.J., Allen, H., Haines, P.W., Hocking, R.M., McDonald, B.J., Belousova, E., Goodall, J., 2016. The answers are blowin' in the wind: ultra-distal ashfall zircons, indicators of Cretaceous super- eruptions in eastern Gondwana. Geology 44 (8), 643-646.

Barham, M., Reynolds, S., Kirkland, C.L., O'Leary, M.J., Evans, N.J., Allen, H., Haines, P.W., Hocking, R.M., McDonald, B.J., 2018. Sediment routing and basin evolution in Proterozoic to Mesozoic east Gondwana: a case study from southern Australia. Gondwana Res. 58, 122-140.

Bartholomai, A., Molnar, R.E., 1981. Muttaburrasaurus, a new iguanodontid (Ornithischia: Ornithopoda) dinosaur from the Lower Cretaceous of Queensland. Mem. Queensland Mus. 20, 319-349.

Bell, P.R., Cau, A., Fanti, F., Smith, E., 2016. A large-clawed theropod (Dinosauria: Tetanurae) from the Lower Cretaceous of Australia and the Gondwanan origin of megaraptorid theropods. Gondwana Res. 36, 473-487.

Bell, P.R., Burns, M.E., Smith, E., 2017. A probable ankylosaurian (Dinosauria, Thyreophora) from the Early Cretaceous of New South Wales, Australia. Alcheringa. https://doi.org/10.1080/03115518.2017.1384851.

Bell, P.R., Herne, M.C., Brougham, T., Smith, E.T., 2018. Ornithopod diversity in the Griman Creek Formation (Cenomanian), New South Wales, Australia. PeerJ 6, e6008.

https://doi.org/10.7717/peerj.6008

Bell, P.R., Brougham, T., Herne, M.C., Frauenfelder, T., Smith, E.T., 2018a. Fostoria dhimbangunmal gen. et sp. nov., a new iguanodontian (Dinosauria, Ornithopoda) from the mid-Cretaceous of Lightning Ridge, NSW, Australia. J. Vertebr. Paleontol (in press).

Benson, R.B.J., Druckenmiller, P.S., 2014. Faunal turnover of marine tetrapods during the Jurassic-Cretaceous transition. Biol. Rev. 89, 1-23. https://doi.org/10.1111/brv. 12038.

Benson, R.B.J., Rich, T.H., Vickers-Rich, P., Hall, M., 2012. Theropod fauna from southern Australia indicates high polar diversity and climate-driven provinciality. PLoS One 7, e37122.

Birch, W.D., 2003. Geology of Victoria. Geol. Soc. Aust. Spec. Publ. 23, 1-842.

Brougham, T., Smith, E.T., Bell, P.R., 2017. Isolated teeth of Anhangueria (Pterosauria: Pterodactyloidea) from the Lower Cretaceous of Lightning Ridge, New South Wales, Australia. PeerJ 5, e3256.

Bryan, S.E., Constantine, A.E., Stephens, C.J., Ewart, A., Schön, R.W., Parianos, J., 1997. Early Cretaceous volcano-sedimentary successions along the eastern Australian continental margin: Implications for the break-up of eastern Gondwana. Earth Planet. Sci. Lett. 153, 85-102.

Burger, D., 1980. Palynological studies in the Lower Cretaceous of the Surat Basin. Aust. Bur. Mineral. Resour. Bull. 189, 1-69.

Burger, D., 1990. Early Cretaceous angiosperms from Queensland, Australia. Rev. Palaeobot. Palynol. 65, 153-163.

Cerda, I.A., Paulina Carabajal, A., Salgado, L., Coria, R.A., Reguero, M.A., Tambussi, C.P., Moly, J.J., 2012. The first record of a sauropod dinosaur from Antarctica.

Naturwissenshaften 99, 83-87.

Chapman, F., 1914. On a new species of Ceratodus from the Cretaceous of New South Wales. Proc. R. Soc. Vic. 27, 25-27.

Clemens, W.A., Wilson, G.P., Molnar, R.E., 2003. An enigmatic (synapsid?) tooth from the Early Cretaceous of New South Wales, Australia. J. Vertebr. Paleontol. 23 (1), 232-237.

Cohen, K.M., Finney, S.C., Gibbard, P.L., Fan, J.X., 2013. The ICS international chronostratigraphic chart. Episodes 36 (3), 199-204.

Cook, A., 2012. Cretaceous faunas and events, northern Eromanga Basin, Queensland. Episodes 35, 153-159.

Cook, A.G., Bryan, S.E., Draper, J., 2013. Post-orogenic Mesozoic basins and magmatism. In: Cook, A.G., Jell, J.S., Jell, P.A. (Eds.), Geology of Queensland. Geological Survey of Queensland, Brisbane, pp. 515-576.

Day, R.W., 1969. The Early Cretaceous of the Great Artesian Basin. In: Campbell, K.S.W. (Ed.), Stratigraphy and Palaeontology. Essays in Honour of Dorothy Hill. Australian University Press, Canberra, pp. 140-173.

Dettman, M.E., Molnar, R.E., Douglas, J.G., Burger, D., Fielding, C., Clifford, H.T., Francis, J., Jell, P., Rich, T., Wade, M., Rich, P.V., Pledge, N., Kemp, A., Rozefelds, A., 1992. Australian Cretaceous terrestrial faunas and floras: biostratigraphic and biogeographic implications. Cretac. Res. 13, 207-262.

Dettmann, M.E., 1963. Upper Mesozoic microfloras from south-eastern Australia. Proc. R. Soc. Vic. 77, 1-148.

Dickinson, W.R., Gehrels, G.E., 2009. Use of U-Pb ages of detrital zircons to infer maximum depositional ages of strata: a test against a Colorado Plateau Mesozoic data-

base. Earth Planet. Sci. Lett. 288, 115-125.

Elhlou, S., Belousova, E.A., Griffin, W.L., Pearson, N.J., O'Reilly, S.Y., 2006. Trace element and isotopic composition of GJ-red zircon standard by laser ablation. Geochim. Cosmochim. Acta 70, 107-115.

Etheridge, R., 1917. Opalised reptilian dentary from Lightning Ridge. Proc. R. Soc. Vic. 29, 127-133.

Exon, N.F., 1976. Geology of the Surat Basin in Queensland. Bur. Miner. Resour. Geol. Geophys. Bull. 166, 1-235.

Flannery, T.F., Archer, M., Rich, T.H., Jones, R., 1995. A new family of monotremes from the Cretaceous of Australia. Nature 377, 418-420.

Glen, R.A., 2013. Refining accretionary orogen models for the Tasmanides of eastern Australia. Aust. J. Earth Sci. 60, 315-370.

Gray, A.R.G., McKillop, M., McKellar, J.L., 2002. Eromanga Basin stratigraphy. In: Draper, J.J. (Ed.), Geology of the Cooper and Eromanga Basins, Queensland. Queensland Minerals and Energy Review Series Queensland Department of Natural Resources and Mines, pp. 30-56.

Green, P.M., Carmichael, D.C., Brain, T.J., Murray, C.G., McKellar, J.L., Beeston, J.W. Gray, A.R.G., 1997. Lithostratigraphic units in the Bowen and Surat basins, Queensland. In: Green, P.M. (Ed.), The Surat and Bowen Basins, South-East Queensland. Queensland Minerals and Energy Review Seriespp. 41-108.

Griffin, W.L., Powell, W.J., Pearson, N.J., O'Reilly, S.Y., 2008. GLITTER: data reduction 
software for laser ablation ICP-MS. In: Sylvester, P. (Ed.), Laser Ablation ICP-MS in the Earth Sciences. Mineralogical Association of Canada Short Course Series 40. Mineralogical Association of Canada, Ottawa, pp. 204-207.

Haig, D.W., Lynch, D.A., 1993. A late early Albian marine transgressive pulse over northeastern Australia, precursor to epeiric basin anoxia: foraminiferal evidence. Mar. Micropaleontol. 22, 311-362.

Hamilton-Bruce, R.J., Kear, B.P., 2006. A new fossil non-marine snail (Gastropoda) from the Lower Cretaceous (Albian, Griman Creek Formation) of eastern Australia. Molluscan Res. 26 (2), 84-88.

Hamilton-Bruce, R.J., Kear, B.P., 2010. A possible succineid land snail from the Lower Cretaceous non-marine deposits of the Griman Creek Formation at Lightning Ridge,

New South Wales. Alcheringa 34 (3), 325-331.

Hamilton-Bruce, R.J., Smith, B.J., Gowlett-Holmes, K.L., 2002. Descriptions of a new genus and two new species of viviparid snails (Mollusca: Gastropoda: Viviparidae) from the Early Cretaceous (middle-late Albian) Griman Creek Formation of Lightning Ridge, northern New South Wales. Rec. S. Aust. Mus. 35 (2), 193-203.

Hamilton-Bruce, R.J., Kear, B.P., Smith, B.J., 2004. A new non-marine Early Cretaceous gastropod species from Lightning Ridge, New South Wales. Alcheringa 28 (2) 485-492. https://doi.org/10.1080/03115510408619297.

Hawke, J.M., Cramsie, J.N., 1984. Contributions to the Geology of the Great Australian Basin in NSW. Geol. Surv. NSW Bull. 31, 1-295.

Hay, W.W., DeConto, R., Wold, C.N., Wilson, K.M., Voigt, S., Schulz, M., Wold-Rossby, A., Dullo, W.-C., Ronov, A.B., Balukhovsky, A.N., Soeding, E., 1999. Alternative global Cretaceous paleogeography. In: Barrera, E., Johnson, C. (Eds.), The Evolution of Cretaceous Ocean/Climate Systems. Geological Society of America Special Paper 332. pp. 1-47.

Heine, C., Yeo, L.G., Müller, R.D., 2015. Evaluating global paleoshoreline models for the Cretaceous and Cenozoic. Aust. J. Earth Sci. 62, 275-287.

Helby, R.J., Moran, R., Partridge, A.D., 1987. A palynological zonation of the Australian Mesozoic. Mem. Aust. Assoc. Palaeontologists 4, 1-94.

Henderson, R.A., Crampton, J.S., Dettmenn, M.E., Douglas, J.G., Haig, D., Shafik, S. Stilwell, J.D., Thulborn, R.A., 2000. Biogeographical observations on the Cretaceous biota of Australasia. Mem. Australas. Assoc. Palaeontologists 23, 355-404.

Herne, M.C., Tait, A.M., Weisbecker, V., Hall, M., Nair, J.P., Cleeland, M., Salisbury, S.W., 2018. A new small-bodied ornithopod (Dinosauria, Ornithischia) from a deep, high-energy Early Cretaceous river of the Australian-Antarctic rift system. PeerJ 5,

Hocke4ull3S.A., 1997. Cretaceous freshwater bivalves from Queensland. Mem. Queensland Mus. 42, 223-226.

Hocknull, S.A., 2000. Mesozoic freshwater and estuarine bivalves from Australia. Mem. Queensland Mus. 45 (2), 405-426.

Hocknull, S.A., Cook, A.G., 2008. Hypsilophodontid (Dinosauria: Ornithischia) from the 212. latest Albian, Winton Formation, central Queensland. Mem. Queensland Mus. 52,

Hocknull, S.A., White, M.A., Tischler, T.R., Cook, A.G., Calleja, N.D., Sloan, T., Elliott, D.A., 2009. New mid-Cretaceous (latest Albian) dinosaurs from Winton, Queensland, Australia. PLoS One 4 (7), e6190.

von Huene, F., 1932. Die fossile Reptil-Ordnung Saurischia, ihre entwicklung und geschichte. Monogr. Geol. Palaeontol. 1, 1-46.

Jackson, S.E., Pearson, N.J., William, L., Griffin, W.L., Belousova, E.A., 2004. The application of laser ablation microprobe inductively coupled plasma-mass spectrometry (LAMICP-MS) to in situ U-Pb zircon geochronology. Chem. Geol. 211, 47-69.

Kear, B.P., 2005. Marine reptiles from the Lower Cretaceous (Aptian) deposits of White Cliffs, southeastern Australia: implications of a high latitude, cold water assemblage. Cretac. Res. 26 (5), 769-782.

Kear, B.P., 2006. Plesiosaur remains from Cretaceous high-latitude non-marine deposit in southeastern Australia. J. Vertebr. Paleontol. 26 (1), 196-199.

Kear, B.P., 2016. Cretaceous marine amniotes of Australia: perspectives on a decade of new research. Mem. Mus. Vic. 74, 17-28.

Kear, B.P., Godthelp, H., 2008. Inferred vertebrate bite marks on an Early Cretaceous unionoid bivalve from Lightning Ridge, New South Wales, Australia. Alcheringa 32, 65-71.

Kear, B.P., Hamilton-Bruce, R.J., 2011. Dinosaurs in Australia. CSIRO Publishing, Australia.

Kear, B.P., Schroeder, N.I., Vickers-Rich, P., Rich, T.H., 2006. Early Cretaceous high-latitude marine reptile assemblages from southern Australia. Paludicola 5, 200-205.

Kemp, A., 1991. Australian Mesozoic and Cainozoic lungfish. In: Vickers-Rich, P., Monaghan, J.M., Baird, R.F., Rich, T.H. (Eds.), Vertebrate Palaeontology of Australasia. Pioneer Design Studio, Melbourne, pp. 465-496.

Kemp, A., 1993. Ceratodus diutinus, a new ceratodont from Cretaceous and late Oligocene-medial Miocene deposits in Australia. J. Paleontol. 67 (5), 883-888.

Kemp, A., 1997a. Four species of Metaceratodus (Osteichthyes: Dipnoi, Family Ceratodontidae) from Australian Mesozoic and Cenozoic deposits. J. Vertebr. Paleontol. 17 (1), 26-33.

Kemp, A., 1997b. A revision of Australian Mesozoic and Cenozoic lungfish of the Family Neoceratodontidae (Osteichthyes: Dipnoi), with a description of four new species. J. Paleontol. 71, 713-733.

Kemp, A., Berrell, R.W., 2013. Lungfish as environmental indicators. In: Arratia, G., Schultze, H.-P., Wilson, M.V.H. (Eds.), Mesozoic Fishes 5 - Global Diversity and Evolution. Verlag Dr. Friedrich Pfeil, Germany, pp. 499-508.

Kemp, A., Molnar, R., 1981. Neoceratodus forsteri from the Lower Cretaceous of New South Wales, Australia. J. Paleontol. 55 (1), 211-217.

Long, J.A., 1998. Dinosaurs of Australia and New Zealand and Other Prehistoric Animals of the Mesozoic Era. University of New South Wales Press, Sydney.

Ludwig, K.R., 2003. Isoplot 3.00. A Geochronological Toolkit for Microsoft Excel. Special Publication No. 4 Berkeley Geochronology Center, pp. 70.

Ludwig, K.R., 2009. User's Manual for Isoplot 3.70. A Geochronological Toolkit for
Microsoft Excel. Berkeley Geochronology Centre Special Publication No. 4. Madzia, D., Boyd, C.A., Mazuch, M., 2018. A basal ornithopod dinosaur from the Cenomanian of the Czech Republic. J. Syst. Palaeontol. 16, 967-979.

Matthews, K.J., Maloney, K.T., Zahirovic, S., Williams, S.E., Seton, M., Müller, R.D., 2016. Global plate boundary evolution and kinematics since the late Paleozoic. Glob. Planet. Chang. 146, 226-250.

McMichael, D.F., 1956. A review of the fossil freshwater mussels (Mollusca, Pelecypoda) of Australasia. Proc. Linnean Soc. NSW 81, 222-244.

Meakin, S., 2011. Geodiversity in the Lightning Ridge area and implications for geotourism. Proc. Linnean Soc. NSW 132, 71-82.

Milan, L.A., Daczko, N.R., Clarke, G.L., Allibone, A.H., 2016. Complexity of in-situ zircon $\mathrm{U}-\mathrm{Pb}-\mathrm{Hf}$ isotope systematics during arc magma genesis at the roots of a Cretaceous arc, Fiordland, New Zealand. Lithos 264, 296-314.

Milan, L.A., Daczko, N.R., Clarke, G.L., 2017. Cordillera Zealandia: a Mesozoic arc flareup on the palaeo-Pacific Gondwana margin. Sci. Rep. 7, 261.

Molnar, R.E., 1980a. Australian late Mesozoic terrestrial tetrapods: some implications. Mem. Soc. Géol. France 139, 131-143.

Molnar, R.E., 1980b. Procoelous crocodile from Lower Cretaceous of Lightning Ridge, New South Wales, Australia. Mem. Queensland Mus. 1, 65-76.

Molnar, R.E., 1980c. Reflections on the Mesozoic of Australia. In: Mesozoic Vertebrate Life. 1. pp. 47-60.

Molnar, R.E., 1990. Problematic Theropoda: 'Carnosaurs'. In: Weishampel, D.B., Dodson, P., Osmólska, H. (Eds.), The Dinosauria. University of California Press, Berkeley, pp. 306-317.

Molnar, R.E., 1996. Observations on the Australian ornithopod dinosaur Muttaburrasaurus. Mem. Queensland Mus. 39, 639-652.

Molnar, R.E., 1999. Avian tibiotarsi from the Early Cretaceous of Lightning Ridge, New South Wales. In: Tomida, Y., Rich, P.V., Vickers-Rich, P. (Eds.), Proceedings of the Second Gondwanan Dinosaur Symposium. National Science Museum Monographs 15. pp. 197-209.

Molnar, R.E., 2011. Sauropod (Saurischia: Dinosauria) material from the Early Cretaceous Griman Creek Formation of the Surat Basin, Queensland, Australia. Alcheringa 35, 303-307.

Molnar, R.E., Galton, P.M., 1986. Hypsilophodontid dinosaurs from Lightning Ridge, New South Wales, Australia. Geobios 19, 231-239. https://doi.org/10.1016/ S0016-6995(86)80046-8.

Molnar, R.E., Salisbury, S.W., 2005. Observations on Cretaceous sauropods from Australia. In: Tidwell, V., Carpenter, K. (Eds.), Thunder-Lizards: The Sauropodomorph Dinosaurs. Indiana University Press, Indianapolis, pp. 454-465.

Molnar, R.E., Willis, P.M.A., 2001. New crocodyliform material from the Early Cretaceous Griman Creek Formation, at Lightning Ridge, New South Wales. In: Grigg, G.C., Seebacher, F., Franklin, C.E. (Eds.), Crocodilian Biology and Evolution. Surrey Beatty \& Sons, NSW, Australia, pp. 75-82.

Molnar, R.E., Flannery, T.F., Rich, T.H.V., 1981. An allosaurid theropod dinosaur from the Early Cretaceous of Victoria, Australia. Alcheringa 5, 141-146.

Moore, M., 2002. Geophysical ground surveys over Lightning Ridge opal prospects. In: Geological Survey of New South Wales Department of Mineral Resources, Geological

Survey Report No. GS2002/442, (43 pp.).

Mortimer, N., Campbell, H.J., Stagpoole, M., Wood, R.A., Rattenbury, M.S., Sutherland, R., Seton, M., 2017. Zealandia: Earth's hidden continent. GSA Today 27 (3), 27-35.

Musser, A.M., 2003. Review of the monotreme fossil record and comparison of palaeontological and molecular data. Comp. Biochem. Physiol. A Mol. Integr. Physiol. 136 (4), 927-942.

Musser, A.M., 2006. Furry egg-layers: monotreme relationships and radiations. In: Scanlon, J., Merrick, J., Archer, M., Hickey, G., Lee, M. (Eds.), Evolution and Biogeography of Australasian Vertebrates. Auscipub, Oatlands, NSW, pp. 523-550.

Newton, R.B., 1915. On some molluscan remains from the opal deposits (Upper Cretaceous) of New South Wales. Proc. Malacol. Soc. Lond. 11, 217-235.

Norman, D.B., 2004. Basal iguanodontia. In: Weishampel, D.B., Dodson, P., Osmólska, H.

(Eds.), The Dinosauria. University of California Press, Berkeley, pp. 413-437. Partridge, A.D., 2006. Jurassic-Early Cretaceous spore-pollen and dinocyst zonations for Australia. In: Monteil, E. (Ed.), Australian Mesozoic and Cenozoic Palynology Zonations-Updated to the 2004 Geologic Time Scale. Geoscience Australia Record 2006/23. CD-ROM.

Phillips, M.J., Bennett, T.H., Lee, M.S.Y., 2009. Molecules, morphology, and ecology indicate a recent, amphibious ancestry for echidnas. Proc. Natl. Acad. Sci. U. S. A. 106

(4), 17089-17094. https://doi.org/10.1073/pnas.0904649106.

Pian, R., Archer, M., Hand, S.J., Beck, R.M.D., Cody, A., 2016. The upper dentition and relationships of the enigmatic Australian Cretaceous mammal Kollikodon ritchiei. Mem. Mus. Vic. 74, 97-105

Poropat, S.F., Mannion, P.D., Upchurch, P., Hocknull, S.A., Kear, B.P., Kundrat, M., Tischler, T.R., Sloan, T., Sinapius, G.H.K., Elliott, J.A., Elliot, D.A., 2016. New Australian sauropods shed light on Cretaceous dinosaur palaeobiogeography. Sci. Rep. 6, 34467

Poropat, S.F., Nair, J.P., Syme, C.E., Mannion, P.D., Upchurch, P., Hocknull, S.A., Cook, A.G., Tischler, T.R., Holland, T., 2017. Reappraisal of Austrosaurus mckillopi Longman, 1933 from the Allaru Mudstone of Queensland, Australia's first named Cretaceous sauropod dinosaur. Alcheringa 41, 543-580.

Poropat, S.F., Martin, S.K., Tosolini, A.-M.P., Wagstaff, B.E., Bean, L.B., Kear, B.P., Vickers-Rich, P., Rich, T.H., 2018. Early Cretaceous polar biotas of Victoria, southeastern Australia-an overview of research to date. Alcheringa 42, 157-229.

Price, P.L., 1997. Permian to Jurassic palynostratigraphic nomenclature of the Bowen and Surat Basins. In: The Surat and Bowen Basins, Southeast Queensland. Queensland Minerals and Energy Review Series Queensland Department of Mines and Energy, pp. 137-148.

Raza, A., Hill, K.C., Korsch, R.J., 2009. Mid-Cretaceous uplift and denudation of the 
Bowen and Surat Basins, eastern Australia: relationship to Tasman Sea rifting from apatite fission-track and vitrinite-reflectance data. Aust. J. Earth Sci. 56, 501-531.

Reiser, R.F., 1970. Stratigraphic nomenclature of the upper part of the Rolling Downs Group in the Surat area. Queensland Gov. Min. J. 71, 301-303.

Rey, P.F., 2013. Opalisation of the Great Artesian Basin (central Australia): an Australian story with a Martian twist. Aust. J. Earth Sci. 60, 291-314.

Rich, T.H., Rich, P., 1989. Polar dinosaurs and biotas of the Early Cretaceous of southeastern Australia. Natl. Geogr. Res. 5, 15-53.

Rich, T.H., Vickers-Rich, P., 1999. The Hypsilophodontidae from southeastern Australia. Natl. Sci. Mus. Monogr. 15, 167-180.

Rich, T.H., Vickers-Rich, P., 2003. Protoceratopsian? ulnae from Australia. Rec. Queen Vic. Mus. 113, 1-12.

Rich, T.H., Kear, B.P., Sinclair, R., Chinnery, B., Carpenter, K., McHugh, M.L., VickersRich, P., 2014. Serendipaceratops arthurclarkei Rich \& Vickers-Rich 2003 is an

Australian Early Cretaceous ceratopsian. Alcheringa 38, 456-479.

Romilio, A., Salisbury, S.W., 2011. A reassessment of large theropod dinosaur tracks from the mid-Cretaceous (late Albian-Cenomanian) Winton Formation of Lark Quarry, central-western Queensland, Australia: a case for mistaken identity. Cretac. Res. 32, $135-142$.

Romilio, A., Tucker, R.T., Salisbury, S.W., 2013. Reevaluation of the Lark Quarry dinosaur Tracksite (late Albian-Cenomanian Winton Formation, central-western Queensland, Australia): no longer a stampede? J. Vertebr. Paleontol. 33, 102-120.

Salisbury, S., Romilio, A., Herne, M.C., Tucker, R.T., Nair, J.P., 2016. The dinosaurian ichnofauna of the Lower Cretaceous (Valanginian-Barremian) Broome Sandstone of the Walmadany Area (James Price Point), Dampier Peninsula, Western Australia. J. Vertebr. Paleontol. 36 (Suppl. 1), 1-152.

Scheibner, E., Basden, H., 1998. Geology of New South Wales - synthesis: geological evolution. Geol. Surv. NSW Mem. (Geol.) 13 (2), 1-666.

Scheibnerova, V., 1984. Micropalaeontology. In: Hawke, J.M., Cramsie, J.N. (Eds.), Contributions to the Geology of the Great Australian Basin in NSW. Geological Survey

of New South Wales Bulletin 31. pp. 161-171.

Senior, B.R., Chadderton, L.T., 2007. Natural gamma radioactivity and exploration for precious opal in Australia. Aust. Gemmol. 23, 160-176.

Smith, E.T., 1999. Black Opal Fossils of Lightning Ridge. Kangaroo Press, Australia.

Smith, E.T., 2009. Terrestrial and Freshwater Turtles of Early Cretaceous Australia (Unpublished Ph.D dissertation). University of New South Wales, Sydney.

Smith, E.T., 2010. Early Cretaceous chelids from Lightning Ridge, New South Wales. Alcheringa 34, 375-384.

Smith, E.T., Kear, B.P., 2013. Spoochelys ormondea gen. et sp. nov., an archaic meiolaniidlike turtle from the Early Cretaceous of Lightning Ridge, Australia. In: Brinkman, Donald B., Holroyd, Patricia A., Gardner, J.D. (Eds.), Morphology and Evolution of Turtles, Vertebrate Paleobiology and Paleoanthropology. Springer Science + Business Media, Dordrecht, pp. 121-146.

Smith Woodward, A., 1910. On remains of a megalosaurian dinosaur from New South Wales. Rep. Br. Assoc. Adv. Sci. 79, 482-483.

Smith, N.D., Makovicky, P.J., Agnolin, F.L., Ezcurra, M.D., Pais, D.F., Salisbury, S.W., 2008. A Megaraptor-like theropod (Dinosauria: Tetanurae) in Australia: support for faunal exchange across eastern and western Gondwana in the mid-Cretaceous. Proc. R. Soc. B Biol. Sci. 275, 2085-2093.
Thulborn, T., 1990. Dinosaur Tracks. Chapman \& Hall, London, pp. 410.

Thulborn, R.A., 1994. Ornithopod dinosaur tracks from the Lower Jurassic of Queensland. Alcheringa 18, 247-258.

Thulborn, T., 2012. Impact of sauropod dinosaurs on lagoonal substrates in the Broome Sandstone (Lower Cretaceous), Western Australia. PLoS One 7, e36208.

Thulborn, T., 2017. Behaviour of dinosaurian track-makers in the Winton Formation (Cretaceous, Albian-Cenomanian) at Lark Quarry, western Queensland, Australia: running or swimming? Ichnos 24, 1-18.

Thulborn, R.A., Wade, M., 1984. Dinosaur trackways in the Winton Formation (midCretaceous) of Queensland. Mem. Queensland Mus. 21, 413-517.

Tosolini, A.P., McLoughlin, S., Drinnan, A.N., 1999. Stratigraphy and fluvial sedimentary facies of the Neocomian lower Strzelecki Group, Gippsland Basin, Victoria. Aust. J.

Earth Sci. 46, 951-970.

Tucker, R.T., Roberts, E.M., Hu, Y., Kemp, A.I.S., Salisbury, S.W., 2013. Detrital zircon age constraints for the Winton Formation, Queensland: contextualising Australia's Late Cretaceous dinosaur faunas. Gondwana Res. 24, 767-779.

Tucker, R.T., Roberts, E.M., Henderson, R.A., Kemp, A.I.S., 2016. Large igneous province or long-lived magmatic arc along the eastern margin of Australia during the Cretaceous? Insights from the sedimentary record. Geol. Soc. Am. Bull. 128 (9-10), 1461-1480.

Tucker, R.T., Roberts, E.M., Darlington, V., Salisbury, S.W., 2017. Investigating the stratigraphy and palaeoenvironments for a suite of newly discovered mid-Cretaceous vertebrate fossil-localities in the Winton Formation, Queensland, Australia. Sediment. Geol. 358, 210-229.

Tulloch, A.J., Ramezani, J., Kimbrough, D.L., Faure, K., Allibone, A.H., 2009. U-Pb geochronology of mid-Paleozoic plutonism in western New Zealand: Implications for S-type granite generation and growth of the east Gondwana margin. Geol. Soc. Am. Bull. 121 (9-10), 1236-1261.

Tulloch, A., Ramezani, J., Faure, K., Allibone, A., 2010. Early Cretaceous magmatism in New Zealand and Queensland: intra-plate or intra-arc origin. In: New England Orogen, pp. 332-335.

Veevers, J.J., Belousova, E.A., Saeed, A., 2016. Zircons traced from the 700-500 Ma transgondwanan supermountains and the gamburtsev Subglacial Mountains to the Ordovician Lachlan Orogen, Cretaceous Ceduna Delta, and modern channel country, central-Southern Australia. Sediment. Geol. 334, 115-141.

Wagstaff, B.E., Gallagher, S.J., Trainor, J.K., 2012. A new sub-division of the Albian spore-pollen zonation of Australia. Rev. Palaeobot. Palynol. 171, 57-72.

Watkins, J.J., Behr, H.J., Behr, K., 2011. Fossil microbes in opal from Lightning Ridge-implications for the formation of opal. Geol. Surv. NSW Q. Notes 136, 1-20.

White, E.I., 1926. On the occurrence of the genus Epiceratodus in the Upper Cretaceous of New South Wales. Ann. Mag. Nat. Hist. 17, 677-682.

White, M.A., Falkingham, P.L., Cook, A.G., Hocknull, S.A., Elliott, D.A., 2013. Morphological comparisons of metacarpal I for Australovenator wintonensis and Rapator ornitholestoides: implications for their taxonomic relationships. Alcheringa 37, 435-441.

White, M.A., Bell, P.R., Cook, A.G., Poropat, S.F., Elliott, D.A., 2015. The dentary of Australovenator wintonensis (Theropoda, Megaraptoridae); implications for megaraptorid dentition. PeerJ 3, e1512. 